\title{
Behaviour of Cold-formed Stainless Steel Single Shear Bolted Connections at Elevated Temperatures
}

\author{
Yancheng $\mathrm{CAI}^{\mathrm{a}}$, $\quad$ Ben YOUNG ${ }^{\mathrm{b}, *}$ \\ ${ }^{\mathrm{a}, \mathrm{b}}$ Department of Civil Engineering, The University of Hong Kong, Pokfulam Road, Hong Kong.
}

\begin{abstract}
The current design rules on bolted connections of cold-formed stainless steel structures are allows for room (ambient) temperature condition only. Research on structural behaviour of single shear bolted connections at elevated temperatures is limited. In this study, 100 single shear bolted connection specimens and 22 coupon specimens involving three different grades of stainless steel were conducted by using steady state test method in the temperature ranged from 200 to $950{ }^{\circ} \mathrm{C}$. The three different grades of stainless steel are austenitic stainless steel EN 1.4301 (AISI 304) and EN 1.4571 (AISI 316Ti having small amount of titanium) as well as lean duplex stainless steel EN 1.4162 (AISI S32101). Furthermore, different bolts arrangement was also considered in the investigation. Two main failure modes were observed in the single shear bolted connection tests, namely the net section tension and bearing failures. The test results were compared with the predicted strengths calculated from the American Specification, Australian/New Zealand Standard and European Codes for cold-formed stainless steel structures. In calculating the nominal strengths of the connections, the reduced material properties of stainless steel obtained at elevated temperatures were used. It is shown that the strengths of the single shear bolted connections predicted by the specifications are generally conservative at elevated temperatures. A similar tendency of reduction was found when compared the reduction factor of material properties with that of the deterioration of the bolted connection test strengths with the corresponding type of cold-formed stainless steel at elevated temperatures. The austenitic stainless steel type EN 1.4571 (AISI 316Ti) generally performed better than the other two stainless steel types at elevated temperatures.
\end{abstract}

Key words: Experimental investigation; Failure modes; Material properties; Single shear bolted connection; Stainless steel; Steady state tests; Ultimate strength.

\footnotetext{
${ }^{*}$ Corresponding author. Tel.: +852-2859-2674; fax: +852-2559-5337.

E-mail address: young@hku.hk (B. Young).
} 


\section{Introduction}

In recent years, significant progress has been made in developing design rules for stainless steel structures at room temperature, but the performance of fire resistance has received less attention [1]. Bolted connections are one of the common connection types in cold-formed steel structures construction. The design rules of cold-formed stainless steel bolted connections are available in current specifications, i.e. the American Society of Civil Engineers Specification (ASCE) [2], Australian/New Zealand Standard (AS/NZS) [3] and European Code 3 Part 1.4 (EC3-1.4) [4]. Tests of carbon steel bolted connections have been conducted by Zadanfarrokh [5] and Rogers and Hancock [6-8], whereas tests of stainless steel bolted connections have been conducted by Bouchaïr et al. [9] and Cai and Young [10]. It should be noted that these tests were carried out at room (ambient) temperature. However, investigation on structural behaviour of bolted connections of cold-formed stainless steels at elevated temperatures is limited.

Tests of stainless steel material properties at elevated temperatures have been conducted [1 and 11-13]. Baddoo and Burgan [14] proposed a methodology for predicting the structural performance of austenitic stainless steel EN 1.4301 beams and columns at elevated temperatures. Ng and Gardner [15] analyzed the behaviour of stainless steel columns and laterally restrained beams under elevated temperatures. However, investigation of stainless steel bolted connections at elevated temperatures is limited. Yan and Young [16-17] recently studied the structural behaviour of single shear bolted connections of thin sheet carbon steels at elevated temperatures by steady state and transient state test methods. Previous research has shown that the strength and stiffness retention of austenitic stainless steel at elevated temperatures is superior to those of carbon steel [18]. It should be noted that the bolted connection design rules in the current specifications [2-4] are applicable at room temperature condition only.

In this study, the material properties of three different types of stainless steels, namely the austenitic stainless steel EN 1.4301 (AISI 304) and EN 1.4571 (AISI 316Ti having small amount of titanium) as well as lean duplex stainless steel EN 1.4162 (AISI S32101) were firstly determined by tensile coupon tests using the steady state test method for the temperature ranged from 200 to $950{ }^{\circ} \mathrm{C}$. The coupon test results obtained from this study showed a similar trend of deterioration of the material properties at elevated temperatures when compared with those obtained by Chen and Young [13] and the EC 1.2 [19]. Based on the coupon test results at elevated temperatures obtained from this study, six critical high temperature levels were selected for the single shear bolted connection tests. The structural behaviour of the 
bolted connection tests was investigated by varying different grades of stainless steels, different bolt diameters, number of bolts and arrangement of the bolts in 15 series of specimens. The failure modes observed from the tests include the bearing, net section tension and bolt shear. The ultimate strength of single shear bolted connections of different stainless steel types at elevated temperatures were compared, and it was shown that the type EN 1.4571 (AISI 316Ti) stainless steel generally performed better than the other two types of stainless steels at elevated temperatures. A similar tendency of reduction was found when compared the deterioration of the connection strengths with that of the corresponding material properties at elevated temperatures.

The objectives of this study are to present a test program on cold-formed stainless steel single shear bolted connections at elevated temperatures using steady state test method, and the test results compare with the nominal strengths predicted by the ASCE Specification [2], AS/NZS Standard [3] and EC3-1.4 [4] for stainless steel structures. In addition, the load-deformation curves and the failure modes obtained from the tests are useful for numerical analysis of stainless steel bolted connections at elevated temperatures.

\section{Coupon tests}

\subsection{Test device}

The tensile coupon tests at elevated temperatures were conducted using an MTS 810 Universal testing machine. The MTS model 653.04 high temperature furnace was used to heat up the specimen to the specified temperature as shown in Fig. 1. The heating device contains three independent-controlled heating chambers with a maximum temperature up to $1400{ }^{\circ} \mathrm{C}$. Inside each heating chamber, an internal thermal couple was used to measure the air temperature in the furnace. Due to the distance between the internal thermal couples and the coupon specimen, the temperature obtained from the internal thermal couples could be slightly different from the temperature of the coupon specimen. Hence, an external thermal couple was used to measure the actual temperature of the coupon specimen. The external thermal couple was inserted inside the furnace and contacted on the surface of the coupon specimen at mid-length. The temperature obtained from the external thermal couple was recorded as the specimen temperature in this study. The heating rate of the furnace for the coupon tests was approximately 40-60 ${ }^{\circ} \mathrm{C} / \mathrm{min}$, depending on the specified temperature level. Higher heating rate was used as the temperature increases. The MTS model 632.54 F-11 high temperature axial extensometer was used to 
measure the strain of the middle section of the coupon specimen. The extensometer has a gauge length of $25 \mathrm{~mm}$ having a limitation of $\pm 2.5 \mathrm{~mm}$ movement. Therefore, the extensometer was reset once it approaches the range limit during testing such that the complete stress-strain curve of the coupon specimen was obtained.

\subsection{Test specimens}

The coupon test specimens were designed according to the Australian Standard AS-2291 [20]. A total of 22 specimens were conducted to obtain the material properties of the stainless steels at elevated temperatures using steady state test method. The dimensions of the coupon specimen had $6 \mathrm{~mm}$ width and $25 \mathrm{~mm}$ gauge length. The coupon test specimens were extracted from the same batch of stainless steel rectangular hollow sections as those connection specimens. The stainless steel tubes were supplied from STALA Tube Finland in uncut lengths of $3000 \mathrm{~mm}$ and nominal section size $20 \times 50 \times 1.5 \mathrm{~mm}$ (with $\times$ depth $\times$ thickness). The coupon specimens involved three different grades of stainless steel, namely the austenitic stainless steel EN 1.4301 (AISI 304) and EN 1.4571 (AISI 316Ti having small amount of titanium) as well as the lean duplex stainless steel EN 1.4162 (AISI S32101). The lean duplex stainless steel EN 1.4162 (AISI S32101) is a high strength material and it is a relatively new kind of material in civil engineering construction, thus it is not covered in any current design specifications; while the austenitic stainless steels EN 1.4301 (AISI 304) and EN 1.4571 (AISI 316Ti) have a lower strength than lean duplex material. The type EN 1.4571 (AISI 316Ti) contains titanium (element $\mathrm{Ti}$ ) and has good resistance at high temperature. For simplicity, the three types of stainless steels, EN 1.4301 (AISI 304), EN 1.4571 (AISI 316Ti) and EN 1.4162 (AISI S32101) are labeled as types A, T and L, respectively, in the context of this paper.

\subsection{Testing procedure}

Steady state test method was used for both the coupon and bolted connection tests in this study. In this test method, the specimen was firstly heated up to a specified temperature, and then loaded until it failed at a constant temperature throughout the test. During the heating process, the coupon specimen was unrestrained at the bottom end and allowing the specimen free to expand. After reaching the pre-selected temperature level, the specimen temperature was stabilized within a period of 8 to 15 minutes depending on the temperature level, which allows the heat to transfer into the specimen. No axial force was applied in the specimens before stabilization of the specimen temperature was achieved. The bottom end of the 
specimen was then gripped and the tensile load was applied to the specimen by driving the hydraulic actuator of the machine. The coupon tests were conducted by displacement control with the loading rate of $0.50 \mathrm{~mm} / \mathrm{min}$. A data acquisition system was used to record the specimen temperature, specimen strain and applied load at regular intervals during the test. The specimen temperature was recorded by an external thermocouple contacted on the surface of the coupon at the middle.

\subsection{Test results}

The coupon tests at room temperature for the same batch of specimens have been conducted by Cai and Young [10], and the results are shown in Table 1. The mechanical properties of the three types of cold-formed stainless steels include the initial elastic modulus $\left(E_{N}\right) ; 0.2 \%$ proof stress $\left(f_{0.2, N}\right)$; tensile strength $\left(f_{u, N}\right)$; ultimate strain $\left(\varepsilon_{u, N}\right)$, maximum strain after fracture $\left(\varepsilon_{f, N}\right)$ based on a gauge length of $25 \mathrm{~mm}$ and the parameter $n$. The ultimate strain $\left(\varepsilon_{u, N}\right)$ was determined by taking the strain corresponding to the tensile strength. The Ramberg-Osgood parameter $n$ is used to describe the initial non-linear part of the stress-strain curve, and was obtained from the measured $0.01 \%\left(f_{0.01}\right)$ and $0.2 \%\left(f_{0.2}\right)$ proof stresses using the equation $n=$ $\ln (0.01 / 0.2) / \ln \left(f_{0.01} / f_{0.2}\right)$. The deterioration of the material properties is expressed by a series of reduction factors, as listed in Table 2 . The reduction factors $f_{0.2, \mathrm{~T}} / f_{0.2, N}$ and $f_{u, T} / f_{u, N}$ of the three types of stainless steels versus the specimen temperatures are plotted in Fig. 2a and Fig. 2b, respectively. The vertical axis of the graphs is the normalized reduction factors $f_{0.2, \mathrm{~T}} / f_{0.2, N}$ and $f_{u, \mathrm{~T}} / f_{u, N}$, while the horizontal axis plotted against the actual specimen temperatures. It is shown that the reduction factor $f_{u, T} / f_{u, N}$ dropped rapidly in the temperature ranged from 500 to $950{ }^{\circ} \mathrm{C}$. Furthermore, the reduction factors $f_{0.2, \mathrm{~T}} / f_{0.2, \mathrm{~N}}$ and $f_{u, \mathrm{~T}} / f_{u, N}$ were compared with those calculated using the equations proposed by Chen and Young [13] and the factors obtained from EC3-1.2 [19]. It is shown that similar trend of deterioration at elevated temperatures were obtained. The deterioration of different types of stainless steels at elevated temperatures was also compared. It is shown that the austenitic stainless steel type $\mathrm{T}$ having a small amount of titanium has better performance in $0.2 \%$ proof stress than the lean duplex stainless steel type $\mathrm{L}$ and austenitic stainless steel type $\mathrm{A}$ in the temperature ranged from 200 to $950{ }^{\circ} \mathrm{C}$. The stainless steel type $\mathrm{T}$ also has a better performance in ultimate strength than the stainless steel types $\mathrm{A}$ and $\mathrm{L}$ when the temperature exceeded $500{ }^{\circ} \mathrm{C}$. 


\section{Current design rules of cold-formed stainless steel bolted connections}

The current design specifications for bolted connections of stainless steel are applicable to room temperature only [2-4]. Different types of failure modes for cold-formed stainless steel bolted connections are specified in the current design specifications. These failure modes include the bolt in shear, bearing, net section tension, bolt in tension and bolt subject to combined shear and tension. In this study, three types of failure modes were observed, namely the bearing, net section tension and bolt shear. The characteristics of different failure modes of single shear bolted connections of thin sheet carbon steels are illustrated in Yan and Young [16]. The design rules for stainless steel bolted connections in this study are based on the following specifications, including the American Society of Civil Engineers Specification (ASCE) [2] for the design of cold-formed stainless steel members, the Australian/New Zealand Standard (AS/NZS) [3] for cold-formed stainless steel structures, Eurocode 3 - Design of steel structures - Part 1-4: General rules Supplementary rules for stainless steels (EC3-1.4) [4] and Eurocode 3 - Design of steel structures - Part 1-8: Design of joints (EC3-1.8) [21]. The design equations for bolted connections in the ASCE Specification [2] are identical to those in the AS/NZS Standard [3].

The bearing load applied to the steel plate would produce piling up of material in front of the bolt, especially for the specimens that are made of stainless steel plate due to the relatively high ratio between the ultimate strength and yield stress. Furthermore, as displacement control was used to drive the hydraulic actuator of the machine in the tests, the post-ultimate behaviour of the specimens can be recorded. The failure mode of net section tension normally has the characteristic of the necking cross section in the plate and cracks near the bolt holes were observed. The bolt shear failure happens due to the deficiency of the strength or quality of the bolts. Designers can eliminate this immature failure of bolted connections by using more bolts or enlarging the diameter of bolts in the design.

\section{Single shear bolted connection tests}

\subsection{Bolted connection specimen design}

The single shear bolted connection specimens were designed by varying the type of stainless steel and the size of bolt as well as the number and the arrangement of bolts. Totally 15 series of bolted connection specimens were tested at elevated 
temperatures. The detailed dimensions of the specimens are illustrated in Fig. 3. The specimens were cut from stainless steel rectangular hollow sections with a specified length. The overall length of the specimens were ranged from 372-386 mm such that the total length of each assembled specimen was maintained at $690 \mathrm{~mm}$, which ensure that the lapped connection part always located at the center position of the furnace. Each end of the specimen was gripped by a pin apparatus as shown in Fig. 4.

Three different sizes of A4 stainless steel bolts [22] with grade 8.8 were used in this study, namely M6, M8 and M12 bolts. The corresponding size of stainless steel washers and nuts were used. Standard size of bolt holes $\left(d_{o}\right)$ were adopted according to the ASCE [2] and AS/NZS [3] standards, namely the size of bolt hole $\left(d_{o}\right)$ is $1 \mathrm{~mm}$ larger than the nominal bolt diameter $(d)$ if $d$ is smaller than $12 \mathrm{~mm}$, otherwise the $d_{o}$ is $2 \mathrm{~mm}$ larger than $d$. Overall, the spacing in the connected parts could satisfy the minimum requirements from the specifications [2, 3, 21], except in the case when there are two bolt holes perpendicular to the direction of loading or more than two bolt holes, as shown in Figs. 2(c), 2(d) and 2(f). In that case, the perpendicular spacing between the centers of two bolt holes is $22 \mathrm{~mm}$ for M8 bolts, which could still follow the requirements from EC3-1.8 [21], but $2 \mathrm{~mm}$ less than $24 \mathrm{~mm}$ minimum requirements in ASCE Specification [2] and AS/NZS Standard [3].

Lips were designed in each bolted connection specimens as illustrated in Fig. 3. Previous researchers found that standard flat specimens curled out of plane affecting the mode of failure [8] and may not accurately represent the true behaviour of profiled structural members, for example channel sections. Therefore, lips of $10 \mathrm{~mm}$ height were used to prevent the out-of-plane curling at the overlapped connection part. The nominal width and thickness of each connection specimen were $50 \mathrm{~mm}$ and $1.5 \mathrm{~mm}$, respectively. Stainless steel washers were assembled in both sides of the bolt. All bolts were hand-tightened to a torque of approximately $10 \mathrm{Nm}$, which allowed for slip of the connection after applied a small loading.

\subsection{Bolted connection specimen labeling}

The specimens are mainly separated into three groups according to the stainless steel types, namely A, T and L. Each group of bolted connection specimens contain five cases based on the bolt diameter, bolt number and bolt arrangement as illustrated in Fig. 3. Each specimen was labeled by four segments in order to identify the type of stainless steel, the connection type, the number and bolt arrangement as well as the bolt size. For examples, the labels "L-S-1-12" and "A-S-2Pa-8" define the following specimens: 
- The first letter indicates the type of stainless steel of which the bolted connection specimen is assembled, where $\mathrm{L}=\mathrm{EN} 1.4162$ (AISI S32101) and $\mathrm{A}=\mathrm{EN} 1.4301$ (AISI 304).

- The second letter represents the connection type, where "S" means the single shear bolted connection.

- The third segment of the label is the number of bolt used in the connection specimen. " 1 " means that there is one bolt used in the specimen. If the specimen is assembled by two bolts, then the letters "Pa" mean the bolts arranged parallel to the loading direction, while "Pe" perpendicular to the loading direction. The " $2 \mathrm{~Pa}$ " means there are two-parallel bolts in the specimen.

- The fourth part of the label means the nominal diameter of the bolts used in the connection. The number " 12 ” represents the bolt diameter of $12 \mathrm{~mm}$, while "8” stands for $8 \mathrm{~mm}$.

\subsection{Test set-up and procedure}

The test set-up of stainless steel single shear bolted connections at elevated temperatures is shown in Fig. 4. The bolted connection tests were conducted by the same MTS Universal testing machine as the coupon tests. A total of 100 single shear bolted connection specimens including the repeated test specimens were tested in this study under six different elevated temperature levels ranged from 200 to $950{ }^{\circ} \mathrm{C}$. In general, it was found that the reduction factors of $0.2 \%$ proof stress dropped regularly at elevated temperatures, while the ultimate strength of the three types of stainless steels reduced rapidly when temperature goes beyond $500{ }^{\circ} \mathrm{C}$ as shown in Fig. 2 . Hence, the nominal temperatures were chosen as 22 (room temperature) 200, 350, 500, 650, 800 and $950{ }^{\circ} \mathrm{C}$. The test specimen was assembled on a pair of gripping apparatus, which was specially fabricated in order to provide the pin end boundary condition of the test. Two special gaskets were inserted in both grips such that the shear surface of the single shear bolted connection specimen was in-line to the loading direction. The details of the gripping apparatus are shown in Yan and Young [16]. Similar to the coupon tests, an external thermal couple was used to measure the actual temperature of the connection specimen.

Steady state testing method was adopted for the single shear bolted connection tests at elevated temperatures. The specimen was firstly set-up with clamping the top end, while keeping the bottom end free. The external thermal couple was inserted inside the furnace and contacted on the surface of the specimen in the middle of the 
overlapped part. The temperature obtained from the external thermal couple was recorded as the specimen temperature. The furnace was then closed and the temperature was raised to a pre-selected level. The thermal expansion of the specimen was allowed by the free bottom end of the specimen during the heating process. Once the pre-selected temperature was reached, the temperature was hold for a period of 8 to 15 minutes, such that allows the temperature to stabilize and the heat to transform uniformly in the specimen, and then the bottom end of the specimen was gripped. The bolted connection tests were conducted by displacement control with the loading rate of $1.5 \mathrm{~mm} / \mathrm{min}$. The tests were stopped when the loading dropped at least $10 \%$ of the ultimate load or the stroke of the hydraulic actuator exceeded at least $20 \mathrm{~mm}$ movement. A data acquisition system was used to record the furnace air temperature, the specimen temperature and the applied load at regular intervals during the test.

\subsection{Test results}

The test strengths $\left(P_{u, N}\right.$ and $\left.P_{u, T}\right)$ of the single shear bolted connection specimens at room and elevated temperatures are given in Tables 3-7. The cold-formed stainless steel single shear bolted connection test results at room temperature are detailed in [10]. The deterioration of the connection strengths at elevated temperatures was plotted in Fig. 5 separated by the bolt number and bolt arrangement of the connections. The vertical axis of the graphs show the test strengths normalized with the test strength at room temperature $\left(P_{u, T} / P_{u, N}\right)$ for each test series, while the horizontal axis plotted against the actual specimen temperatures. The repeated test specimens were conducted mainly for the nominal temperatures between 200 to $500{ }^{\circ} \mathrm{C}$. This is due to similar connection strengths were obtained. It was found that the ultimate strengths of the connections $P_{u, T}$ dropped rapidly when the temperature exceeded $500{ }^{\circ} \mathrm{C}$. It was also found that the stainless steel type T (EN 1.4571 or AISI 316Ti) generally performed better at elevated temperatures compared with the other two types A (EN 1.4301 or AISI 304) and L (EN 1.4162 or AISI S32101), especially when the temperature exceeded $500{ }^{\circ} \mathrm{C}$. Furthermore, the stainless steel type L generally has a better performance than type A for the temperature ranged from 22 to $500{ }^{\circ} \mathrm{C}$, but type A has a slightly better performance than type $L$ for the temperature ranged from 650 to $950{ }^{\circ} \mathrm{C}$.

The connection strengths normalized with the strength at room temperature for different stainless steel types are plotted in Fig. 6. The vertical axis represents the normalized reduction factors $f_{0.2, \mathrm{~T}} / f_{0.2, N}, f_{u, T} / f_{u, N}$ and $P_{u, T} / P_{u, N}$, while the horizontal axis plotted against the actual specimen temperatures. The material reduction factors $f_{0.2, \mathrm{~T}} / f_{0.2, N}$ and $f_{u, T} / f_{u, N}$ at elevated temperatures were compared with the corresponding 
normalized connection strengths for the three types of stainless steels, as illustrated in Fig. 6. Generally, the deterioration of material properties showed a similar tendency of reduction to that of the connection strengths regardless of different bolt diameters, bolt number and bolt arrangement in all types of stainless steels, except for the one-bolted connection case for the temperature ranged from 200 to $500{ }^{\circ} \mathrm{C}$, in which the reduction factor of connection strengths was slightly increased as the temperature increases in this range. Fig. 7 exemplifies the test curves of one-bolted connection specimens A-S-1-12, T-S-1-12 and L-S-1-12 at different nominal temperatures, in which " $\mathrm{R}$ " represents the repeated test curve. The displacement of bolt slip during the initial loading stage was shifted in all the curves.

\section{Comparison of test strengths with predicted strengths}

The predicted strengths $\left(P_{A S C E}\right.$ and $\left.P_{E C}\right)$ of the single shear bolted connections were calculated using the design equations in the current specifications [2, 4 and 21] with consideration of the deterioration of the material properties at elevated temperatures. In the design calculation, the reduced yield stress and ultimate strength obtained from the coupon tests at elevated temperatures were used. The measured specimen dimensions were used to calculate the nominal connection strengths. The design rules for single shear bolted connections in the ASCE Specification [2] are identical to those in the AS/NZS Standard [3]. Therefore, the predicted values obtained from the two specifications are identical. Tables 3-7 show the comparison of the test results with the predicted values calculated using the ASCE Specification [2], AS/NZS Standard [3] and Eurocodes [4 and 21]. It was found that the predicted strengths $\left(P_{A S C E}\right.$ and $\left.P_{E C}\right)$ of the bolted connections calculated using the ASCE Specification [2] and Eurocodes [4, 21] are conservative at elevated temperatures, except for the Eurocodes predictions for specimens L-S-2Pa-8, T-S-2Pa-8 and T-S-4-6 at the nominal temperatures of 350,950 and $950{ }^{\circ} \mathrm{C}$, respectively. The predictions $P_{A S C E}$ were more conservative than the predictions $P_{E C}$, except for the connection types of one-bolted and two-perpendicular bolted conditions. However, the current design formulas in these three standards by substituting the reduced material properties at elevated temperatures generally underestimate the bearing strength of the stainless steel single shear bolted connections.

Moreover, the bolted connections assembled by austenitic stainless steel types A and $\mathrm{T}$ are generally more conservative compared with the bolted connections using lean duplex stainless steel type L, except for the three-bolted connection specimens predicted by the Eurocodes [4, 21], and the four-bolted connections in all 
specifications. For the one-bolted connection type A as shown in Table 3(a), the mean values of $P_{u, T} / P_{A S C E}$ and $P_{u, T} / P_{E C}$ are 1.72 and 2.16, with the corresponding coefficients of variation (COV) of 0.104 and 0.110 , respectively, for series A-S-1-12 at elevated temperatures, whereas the mean values of $P_{u, T} / P_{A S C E}$ and $P_{u, T} / P_{E C}$ are 1.74 and 2.16, with the corresponding COV of 0.119 and 0.137 , respectively, for series T-S-1-12, as shown in Table 3(b). The mean values of $P_{u, T} / P_{A S C E}$ and $P_{u, T} / P_{E C}$ are 1.63 and 1.99, with the corresponding COV of 0.140 and 0.148 , respectively, for series L-S-1-12, as shown in Table 3(c). The comparison of the test strengths with the predicted strengths for two-parallel bolted, two-perpendicular bolted, three-bolted and four-bolted connections are shown in Tables 4-7.

The deterioration of material properties $\left(f_{0.2, T} / f_{0.2, N}\right.$ and $\left.f_{u, T} / f_{u, N}\right)$ at elevated temperatures can be viewed as the deterioration of the predicted strengths of the stainless steel single shear bolted connections at elevated temperatures. This is due to the fact that the same coefficients in the design formulas are used for both ambient and elevated temperatures. Figs. 6(a)-6(c) show the deterioration of the test strengths of the single shear bolted connections as the temperature increases for cold-formed stainless steel types A, T and L, respectively, except for the one-bolted connections in the temperature range 200 to $500{ }^{\circ} \mathrm{C}$ as mentioned earlier. It was found that the reduction factor of $f_{u, T} / f_{u, N}$ generally showed a similar tendency of reduction with that of the deterioration of test strengths for different bolted connection types.

\section{Failure modes at elevated temperatures}

The observed failure modes of each bolted connection specimen are listed in Tables 3-7. In which, 'B' means the bearing failure; 'NS' stands for the net section tension failure; 'BS' represents the bolt shear failure. Some specimens failed by the interaction of failure modes, such as ' $\mathrm{B}+\mathrm{NS}$ ' that means the specimen failed by combination of bearing and net section tension failure modes. Generally, most of the specimens were failed by bearing failure based on the experimental observation. While it was found that the characteristics of the bearing failure mode developed at elevated temperatures, including the bolt hole elongation, the tilting of the bolt and the steel material piling up in front of the bolt as found in Yan and Young [16]. The tear out failure (end pull out failure) mode was not observed in any tested specimens. Therefore, the distance of $3 d_{o}$ from the center of bolt hole to the end of the plate is generally sufficient to prevent tear out failure in the single shear bolted connections at elevated temperatures. The bearing failure mode of the specimens in series A-S-1-12 at different temperatures is shown in Fig. 8. 
The bolted connection specimens assembled by stainless steel type A were failed mainly by bearing failure at elevated temperatures, except the specimens in Series A-S-3-8 the net section tension failure mode also involved in the temperatures ranged from 22 to $500{ }^{\circ} \mathrm{C}$. It should be noted that bolt shear failure was found in specimen A-S-4-6 at room temperature, but only bearing failure occurred at elevated temperatures. The stainless steel type $\mathrm{T}$ having small amount of titanium are also mainly failed in bearing. The bolt shear failure was deliberately avoided in the design of the test specimens at ambient temperature, but this failure mode was observed in the stainless steel bolted connection specimens T-S-2Pa-8, T-S-2Pe-8 and T-S-4-6 for the temperatures ranged from 650 to $950{ }^{\circ} \mathrm{C}$, except for specimen T-S-2Pa-8 at the temperature $650{ }^{\circ} \mathrm{C}$. The net section tension failure was observed together with the bearing failure for specimens in Series T-S-3-8 in the temperature ranged from 22 to $650{ }^{\circ} \mathrm{C}$, while net section tension failure was not observed when the temperature exceeded $800{ }^{\circ} \mathrm{C}$. The bearing failure mode was also found in stainless steel type $\mathrm{L}$ connection specimens. In addition, bolt shear failure was also found in specimens L-S-2Pa-8 and L-S-2Pe-8 for the temperatures ranged from 22 to $500{ }^{\circ} \mathrm{C}$. However, net section tension and bearing failure were found in specimens L-S-3-8 and L-S-4-8 for the temperatures ranged from 22 to $500{ }^{\circ} \mathrm{C}$. As the temperature increases, only bearing failure mode was found when the temperature exceeded $650^{\circ} \mathrm{C}$.

\section{Conclusions}

An experimental investigation on the strengths and failure modes of stainless steel single shear bolted connections at elevated temperatures has been presented. Three types of cold-formed stainless steels with nominal thickness $1.50 \mathrm{~mm}$ were investigated. The three types of stainless steel are austenitic stainless steel EN 1.4301 (AISI 304) and EN 1.4571 (AISI 316Ti having small amount of titanium) as well as lean duplex stainless steel EN 1.4162 (AISI S32101). A total of 22 coupon tests was conducted in order to investigate the deterioration of the material properties at elevated temperatures and to determine the critical temperatures for the bolted connections. A total of 100 connection specimens varied in bolt diameter, bolt number and bolt arrangement were tested in six different temperature levels. The steady state test method was used for conducting the coupon tests and the connection tests. The $0.2 \%$ proof stresses $\left(f_{0.2}\right)$ and tensile strengths $\left(f_{u}\right)$ of the 3 types of cold-formed stainless steels obtained from the coupon tests were compared with the values predicted by Chen and Young's proposed equations [13] and EC3-1.2 [19]. The comparison showed a similar trend of deterioration at elevated temperatures. 
The deterioration of different types of stainless steel properties at elevated temperatures was also compared. It is shown that the austenitic stainless steel type EN 1.4571 (AISI 316Ti) has better performance in $0.2 \%$ proof stress than the lean duplex stainless steel type EN 1.4162 (AISI S32101) and austenitic stainless steel type EN 1.4301 (AISI 304) in the temperature ranged from 200 to $950{ }^{\circ} \mathrm{C}$. The stainless steel type EN 1.4571 also has a better performance in ultimate strength than the stainless steel types EN 1.4301 and EN 1.4162 when the temperature exceeded $500{ }^{\circ} \mathrm{C}$. This is similar case when comparing the bolted connection test strengths, as the stainless steel type EN 1.4571 generally performed better at elevated temperatures compared with the other two types EN 1.4301 and EN 1.4162, especially when the temperature exceeded $500{ }^{\circ} \mathrm{C}$. Furthermore, bolted connections of the stainless steel type EN 1.4162 generally has a better performance than type EN 1.4301 for the temperature ranged from 22 to $500{ }^{\circ} \mathrm{C}$, but type EN 1.4301 has a slightly better performance than type EN 1.4162 for the temperature ranged from 650 to $950{ }^{\circ} \mathrm{C}$.

The test strengths of the single shear bolted connections were compared with the predicted strengths calculated from the ASCE Specification [2], AS/NZS Standard [3] and Eurocodes [4 and 21] for cold-formed stainless steel structures by using the reduced material properties due to high temperatures. In the design calculation, the reduced yield stress and ultimate strength obtained from the coupon tests at elevated temperatures were used. It was found that the predicted strengths by the ASCE Specification and Eurocodes for the bolted connections are generally conservative at elevated temperatures. The ASCE predictions are more conservative than the Eurocode predictions, except for the connection types of one-bolted and two-perpendicular bolted conditions. However, the current design formulas in these three standards by substituting the reduced material properties at elevated temperatures generally underestimate the bearing strength of the stainless steel single shear bolted connections. Moreover, the bolted connections assembled by austenitic stainless steel types EN 1.4301 and EN 1.4571 are generally more conservative compared with the bolted connections using lean duplex stainless steel type EN 1.4162, except for the three-bolted connection specimens predicted by the Eurocodes, and the four-bolted connections in all specifications. Generally, the stainless steel single shear bolted connections were failed by bearing at elevated temperatures. Furthermore, it was found that the reduction factor of $f_{u, T} / f_{u, N}$ obtained from coupon tests showed a similar tendency of reduction with those of the connection tests. 


\section{Acknowledgements}

The authors are grateful to STALA Tube Finland for supplying the test specimens. The authors are also thankful to $\mathrm{Mr}$ Ho-hin CHAU for his assistance in the experimental program as part of his final year undergraduate research project at The University of Hong Kong. The research work described in this paper was supported by a grant from the Research Grants Council of the Hong Kong Special Administrative Region, China (Project No. HKU718612E).

\section{References}

[1] Gardner, L. and Baddoo, N.R. Fire testing and design of stainless steel structures. Journal of Constructional Steel Research 2006; 62(6): 532-543.

[2] American Society of Civil Engineers (ASCE). Specification for the design of cold-formed stainless steel structural members. ASCE Standard, SEI/ASCE-8-02, Reston, Virginia, 2002.

[3] Australian/New Zealand Standard (AS/NZS). Cold-formed stainless steel structures. AS/NZS 4673:2001, Standards Australia, Sydney, Australia, 2001.

[4] EC3-1.4. Eurocode 3. Design of steel structures - Part 1.4: General rules Supplementary rules for stainless steels, European Committee for Standardization, BS EN 1993-1-4:2006, CEN, Brussels, 2006.

[5] Zadanfarrokh F. Analysis and design of bolted connections in cold formed steel members, PhD Thesis, The University of Salford, 1991.

[6] Rogers, C.A. and Hancock, G.J. Bolted connection tests of thin G550 and G300 sheet steels. Journal of Structural Engineering ASCE 1998; 124 (7): 798-808.

[7] Rogers, C.A. and Hancock, G.J. Bolted connection design for sheet steels less than $1.0 \mathrm{~mm}$ thick. Journal of Constructional Steel Research 1999; 51(2): 123-146.

[8] Rogers, C.A. and Hancock, G.J. Failure modes of bolted-sheet-steel connections loaded in shear. Journal of Structural Engineering ASCE 2000; 126(3): 288-296.

[9] Bouchaïr, A., Averseng, J., and Abidelah, A. Analysis of the behaviour of stainless steel bolted connections. Journal of Constructional Steel Research 2008; 64(11): 1264-1274.

[10] Cai, Y., and Young, B. Structural behaviour of cold-formed stainless steel bolted connections. The 4th International Experts Seminar on Stainless Steel in Structures, Steel Construction Institute, UK, 2012.

[11] Sakumoto, Y., Nakazato, T. and Matsuzaki, A. High-temperature properties of stainless steel for building structures. Journal of Structural Engineering, ASCE 1996; 
Vol. 122(4), 399-406.

[12] Makelainen, P., and Outinen, J. Mechanical properties of an austenitic stainless Steel at elevated temperatures. Journal of Constructional Steel Research 1998; Vol. 46(1-3), 455.

[13] Chen, J., and Young, B. Stress-strain curves for stainless steel at elevated temperatures. Engineering Structures 2006; Vol. 28(2), 229-239.

[14] Baddoo, N.R. and Burgan, B.A. Fire resistant design of austenitic structural stainless steel. Journal of Constructional Steel Research 1998; Vol. 46(1-3), 458-459.

[15] Ng, K.T. and Gardner, L. Buckling of stainless steel columns and beams in fire. Engineering Structures 2007; Vol. 29(5), 717-730.

[16] Yan, S. and Young, B. Tests of single shear bolted connections of thin sheet steels at elevated temperatures - Part I: Steady state tests. Thin-Walled Structures 2011, 49(10): 1320-1333.

[17] Yan, S. and Young, B. Tests of single shear bolted connections of thin sheet steels at elevated temperatures - Part II: Transient state tests. Thin-Walled Structures 2011, 49(10): 1334-1340.

[18] Gardner, L., and Ng, K.T. Temperature development in structural stainless steel sections exposed to fire. Fire Safety Journal 2006; Vol. 41(3), 185-203.

[19] EC3-1.2. Eurocode 3: Design of steel structures-Part 1.2: General rules-Structural fire design, European Committee for Standardization, BS EN 1993-1-2:2005, CEN, Brussels, 2005.

[20] AS-2291:1979. Methods for the tensile testing of metals at elevated temperatures. Sydney, Australia: Standards Australia; 1979.

[21] EC3-1.8. Eurocode 3: Design of steel structures-Part 1.8: Design of joints. European Committee for Standardization, BS EN 1993-1-8:2005, CEN, Brussels, 2005.

[22] BS EN ISO 3506-1. Mechanical properties of corrosion-resistant stainless steel fasteners_-Part 1: Bolts, screws and studs; BS EN ISO 3506-1: 1998. 


\section{Nomenclature}

$d=$ nominal diameter of stainless steel bolt;

$d_{0}=$ nominal diameter of bolt hole;

$E_{N}=$ the elastic modulus at room (ambient) temperature;

$E_{T} \quad=\quad$ the elastic modulus at elevated temperatures;

$f_{0.01}=$ longitudinal $0.01 \%$ tensile proof stress;

$f_{0.2}=$ longitudinal $0.2 \%$ tensile proof stress;

$f_{0.2, N}=$ longitudinal $0.2 \%$ tensile proof stress at room temperature;

$f_{0.2, T}=$ longitudinal $0.2 \%$ tensile proof stress at elevated temperatures;

$f_{u}=$ longitudinal tensile strength;

$f_{u, N}=$ longitudinal tensile strength at room temperature;

$f_{u, T}=$ longitudinal tensile strength at elevated temperatures;

$\varepsilon_{u, N}=$ ultimate strain at room temperature;

$\varepsilon_{u, T}=$ ultimate strain at elevated temperatures;

$\varepsilon_{f, N} \quad=\quad$ elongation (longitudinal tensile strain) at fracture at room temperature;

$n=$ exponent in the Ramberg-Osgood expression;

$P_{u, N}=$ ultimate load of bolted connection test at room temperature;

$P_{u, T}=$ ultimate load of bolted connection test at elevated temperatures;

$P_{u, E C}=$ predicted strength of bolted connection based on Eurocodes;

$P_{u, A S C E}=$ predicted strength of bolted connection based on ASCE Specification;

$P_{u, A S / N Z S}=$ predicted strength of bolted connection based on AS/NZS Standard. 


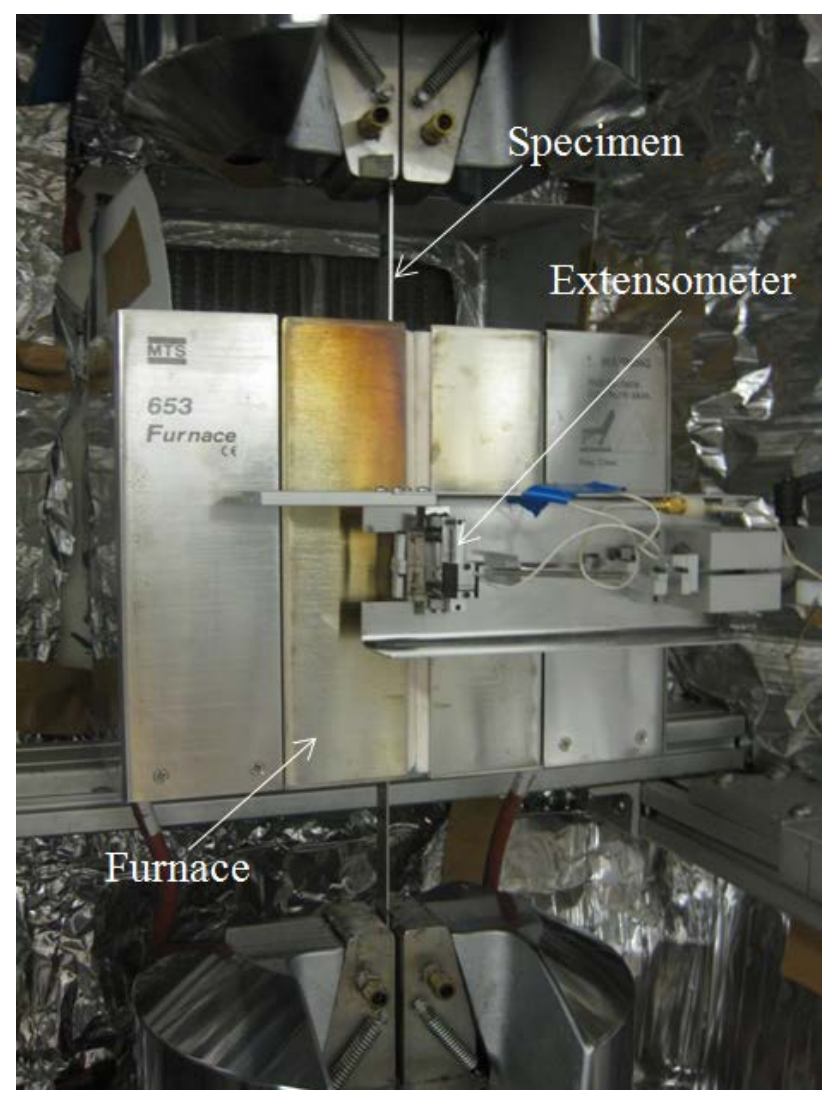

Fig. 1. Testing device of coupon test at elevated temperatures 


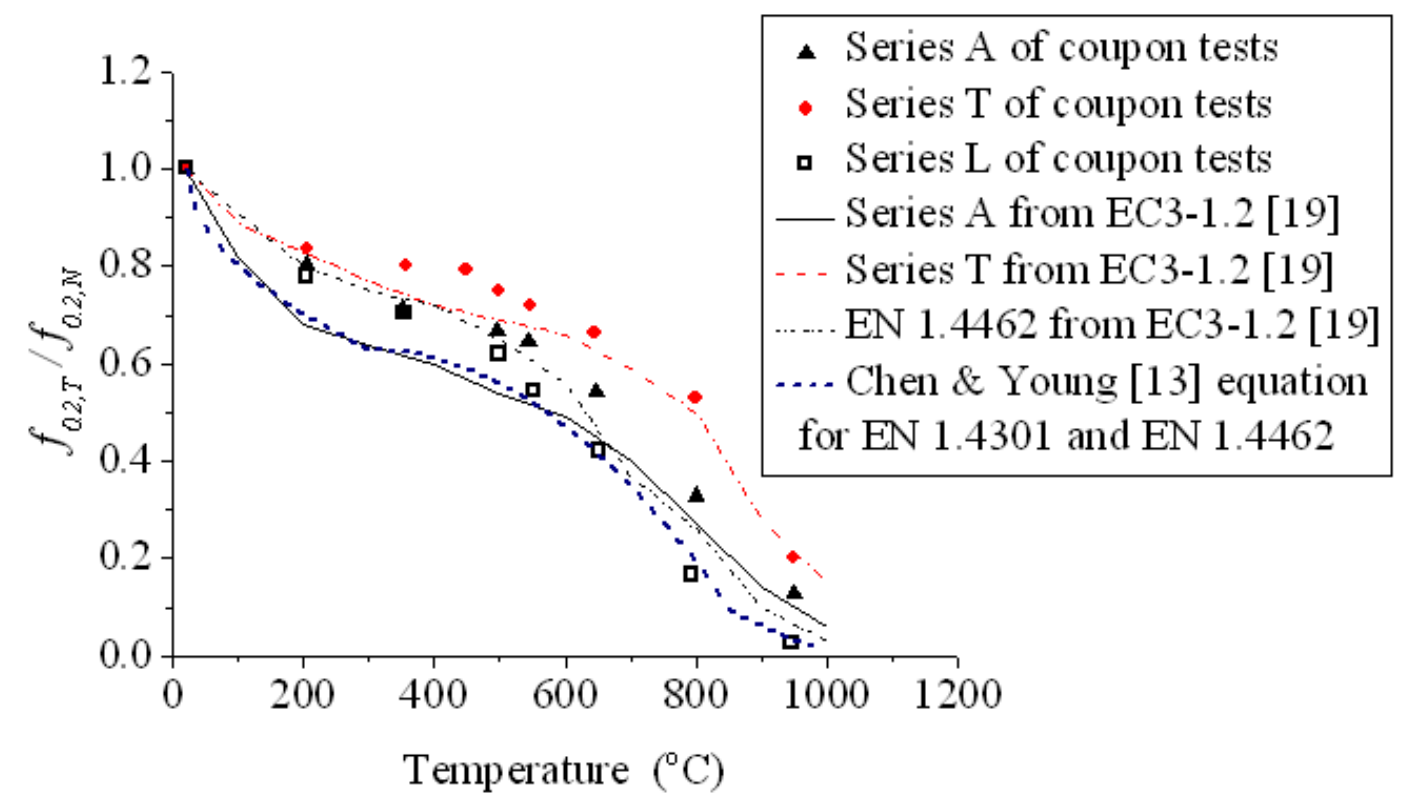

(a) $0.2 \%$ proof stress

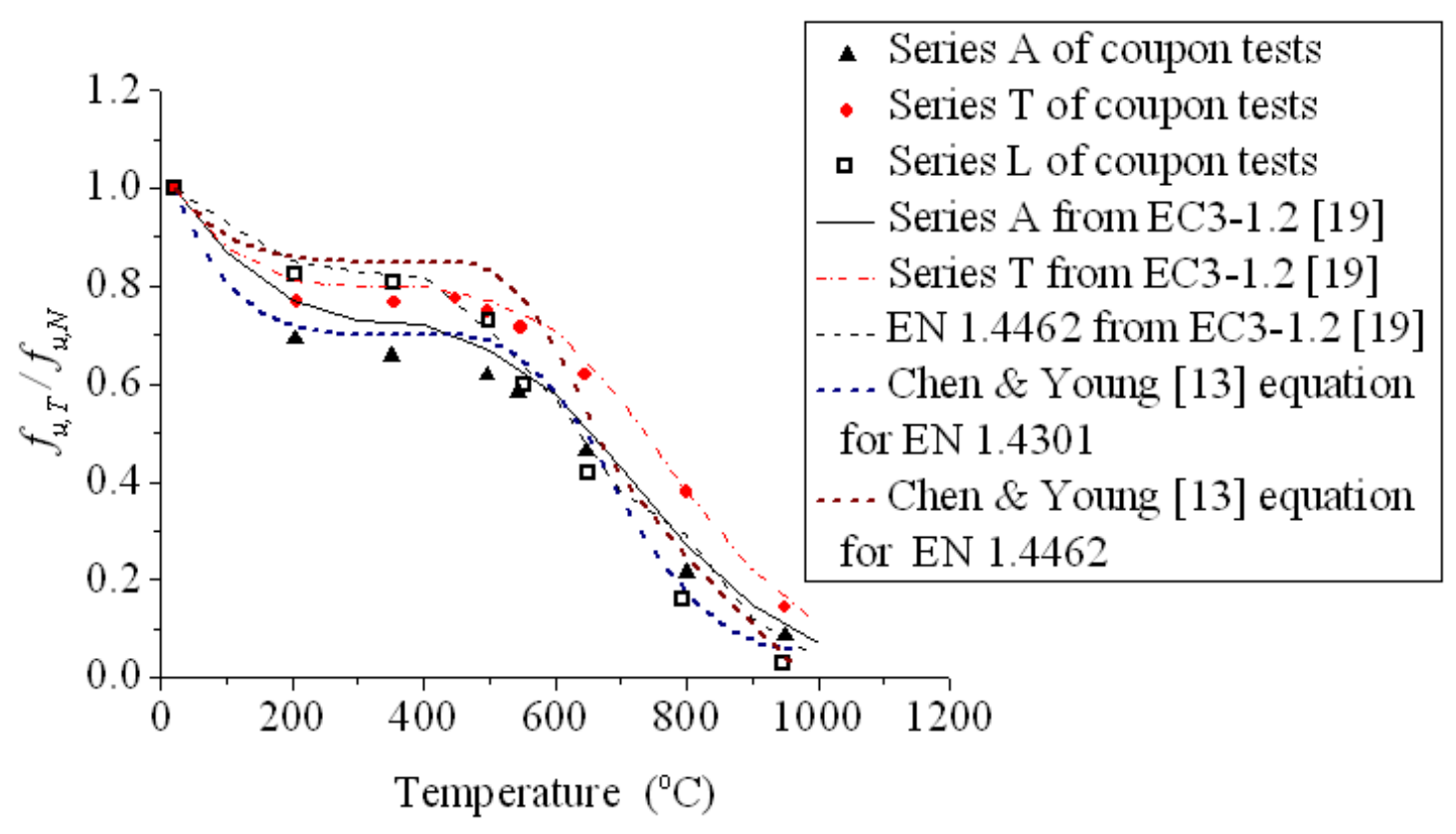

(b) Tensile strength

Fig. 2. Comparison of coupon test results with material properties predicted by Chen and Young [13] and EC-3 1.2 [19] 


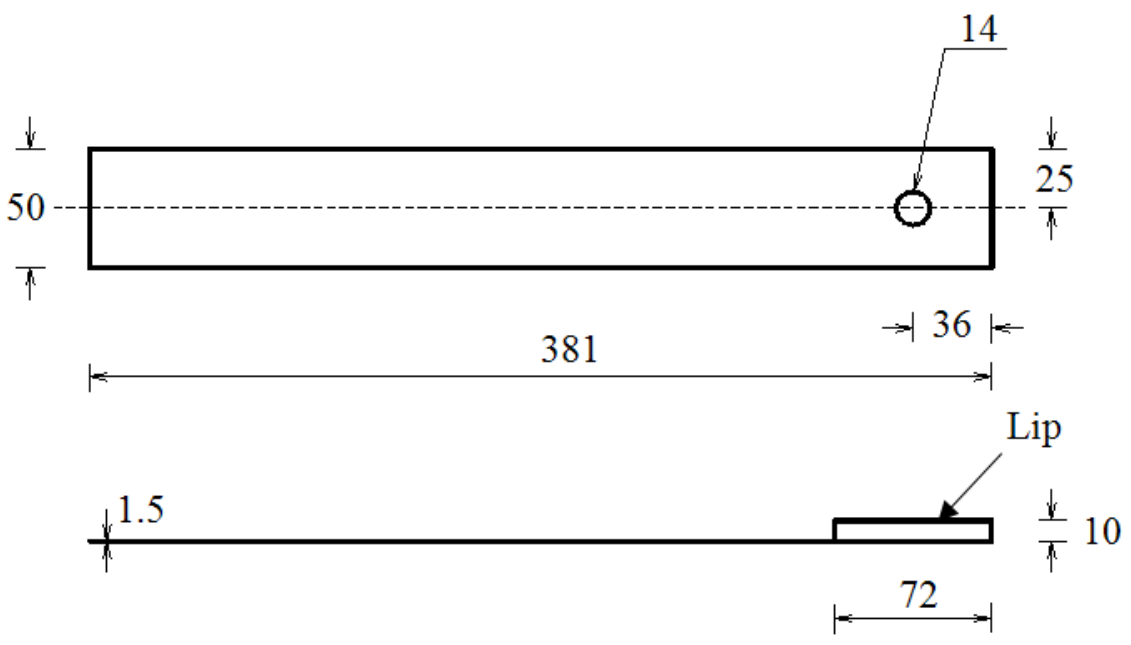

(a) One-bolted M12 of series A, T and L

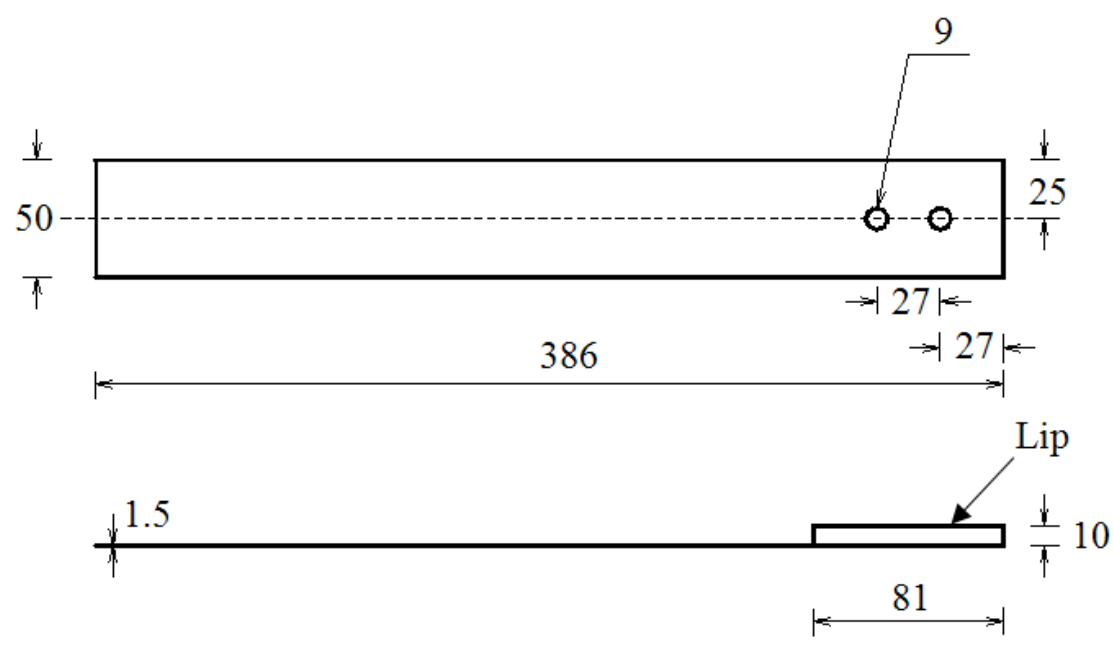

(b) Two-parallel bolted M8 of series A, T and L

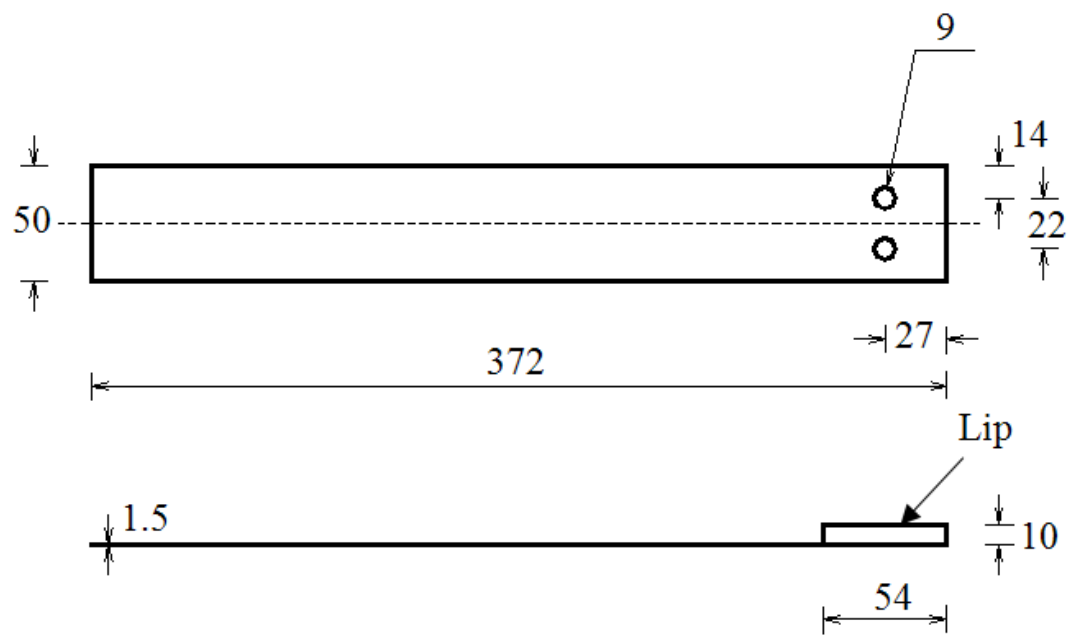

(c) Two-perpendicular bolted M8 of series A, T and L 


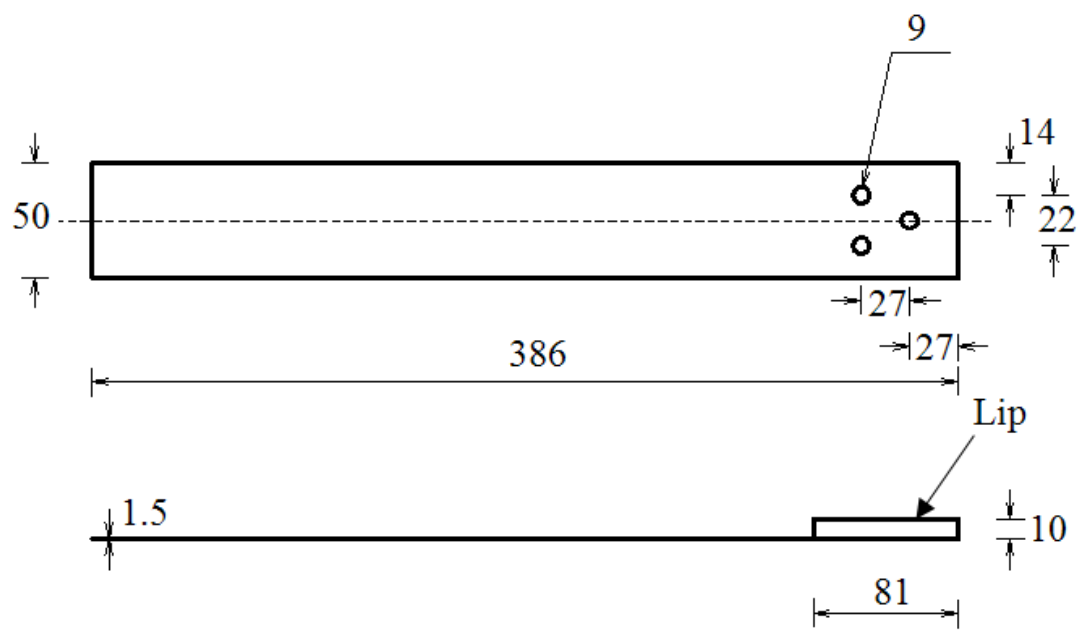

(d) Three-bolted M8 of series A, T and L

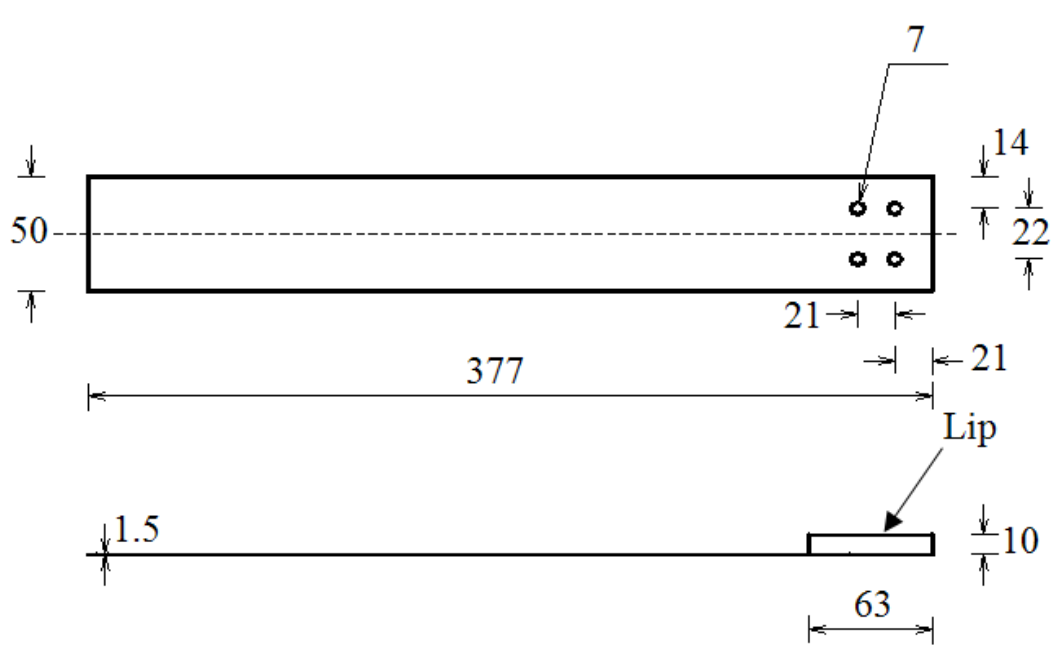

(e) Four-bolted M6 of series A and T

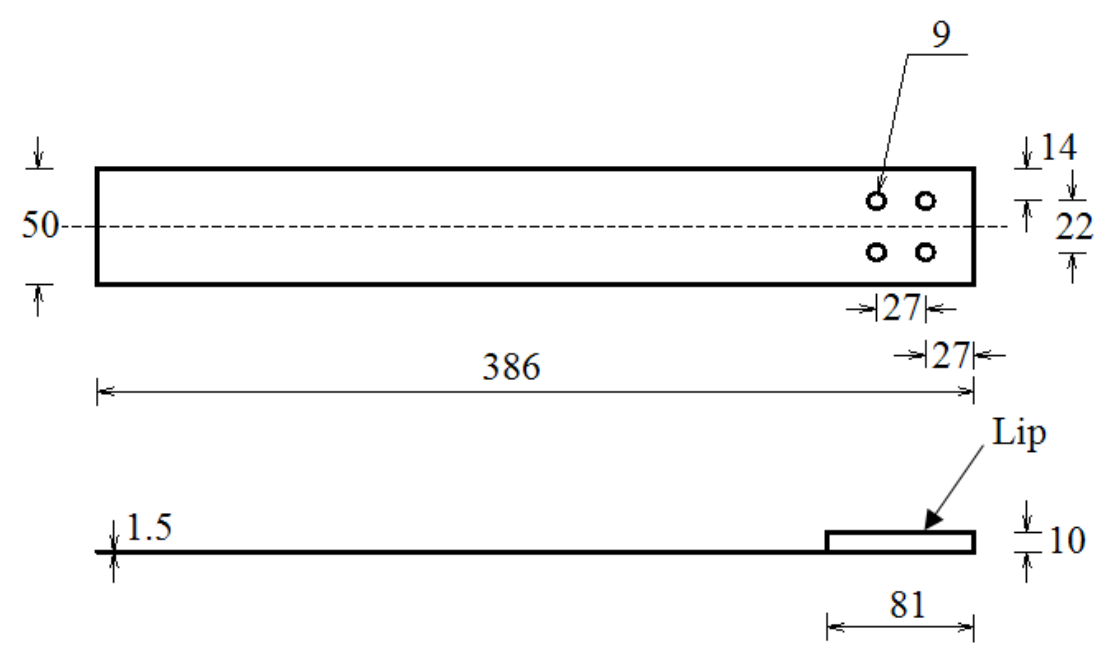

(f) Four-bolted M8 of Series L

Fig. 3. Nominal dimensions of bolted connection specimens 


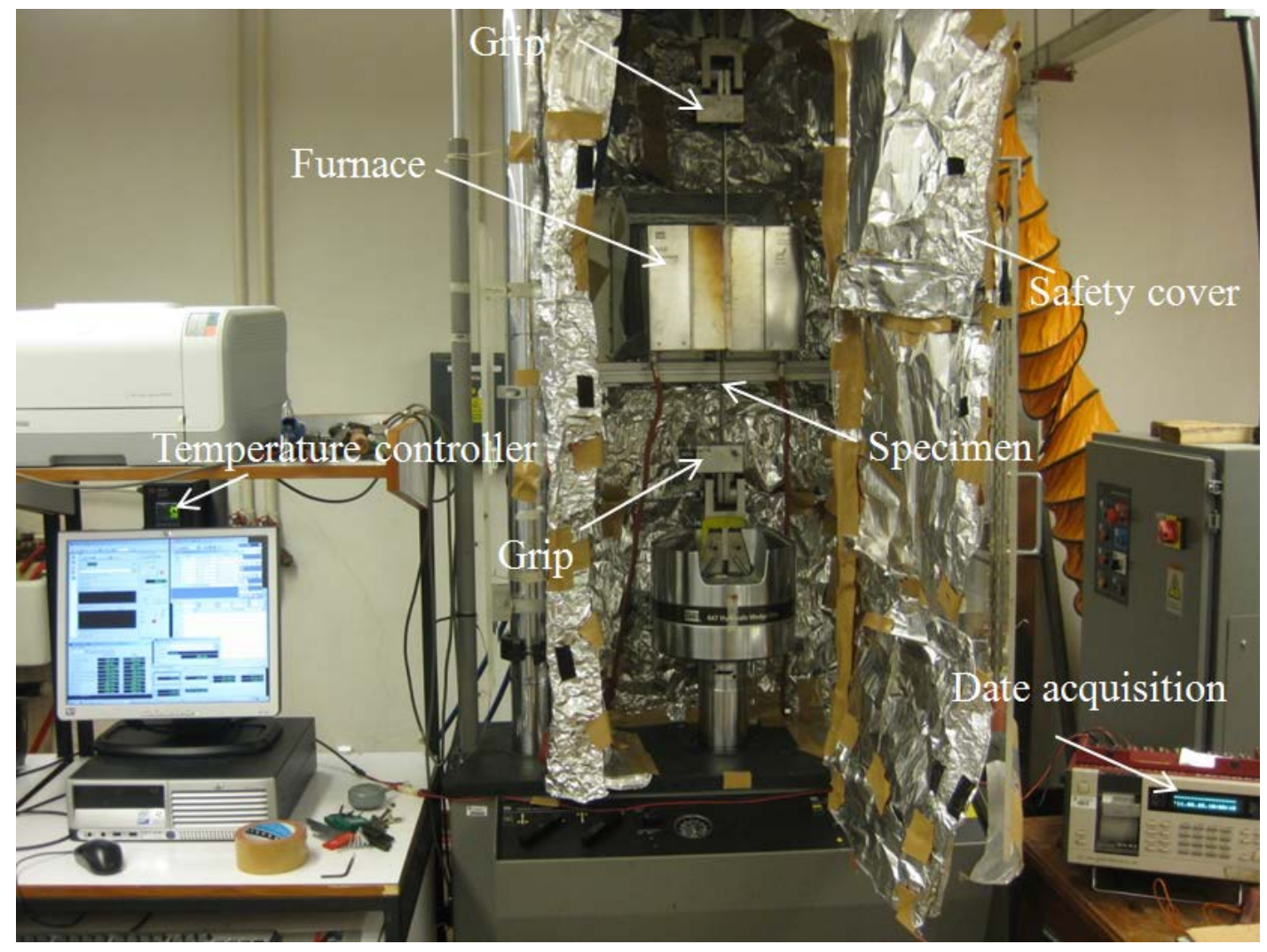

Fig. 4. Test set-up of single shear bolted connection at elevated temperatures 


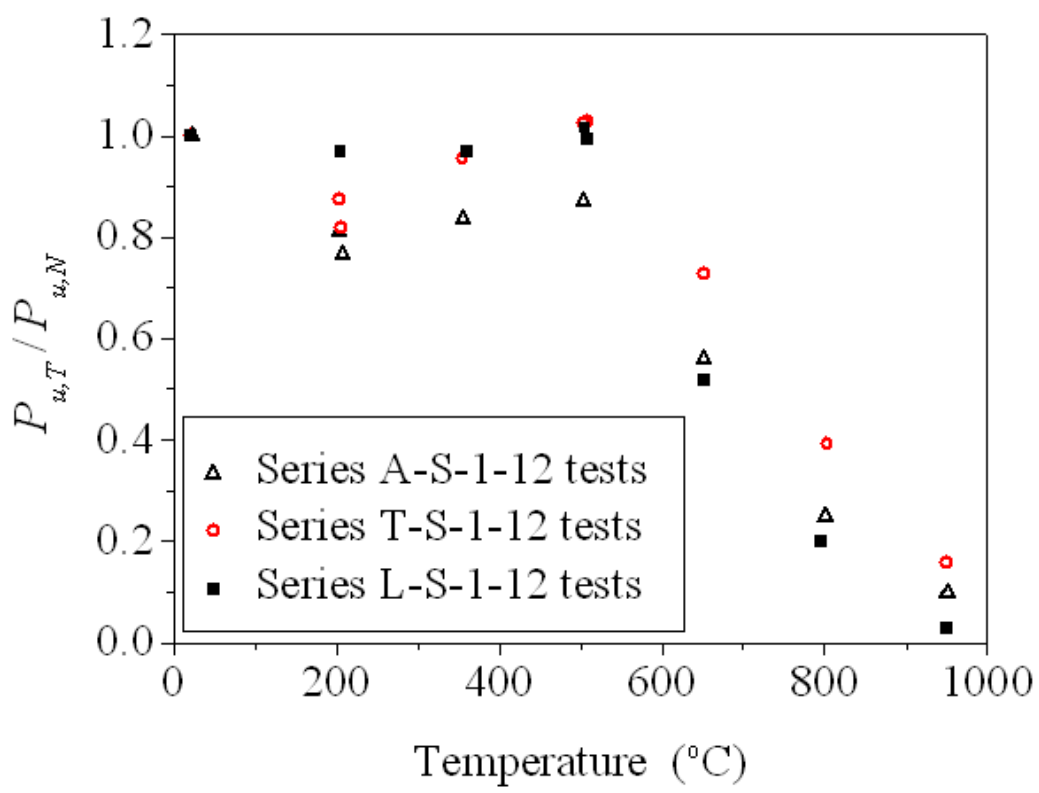

(a) One-bolted connections

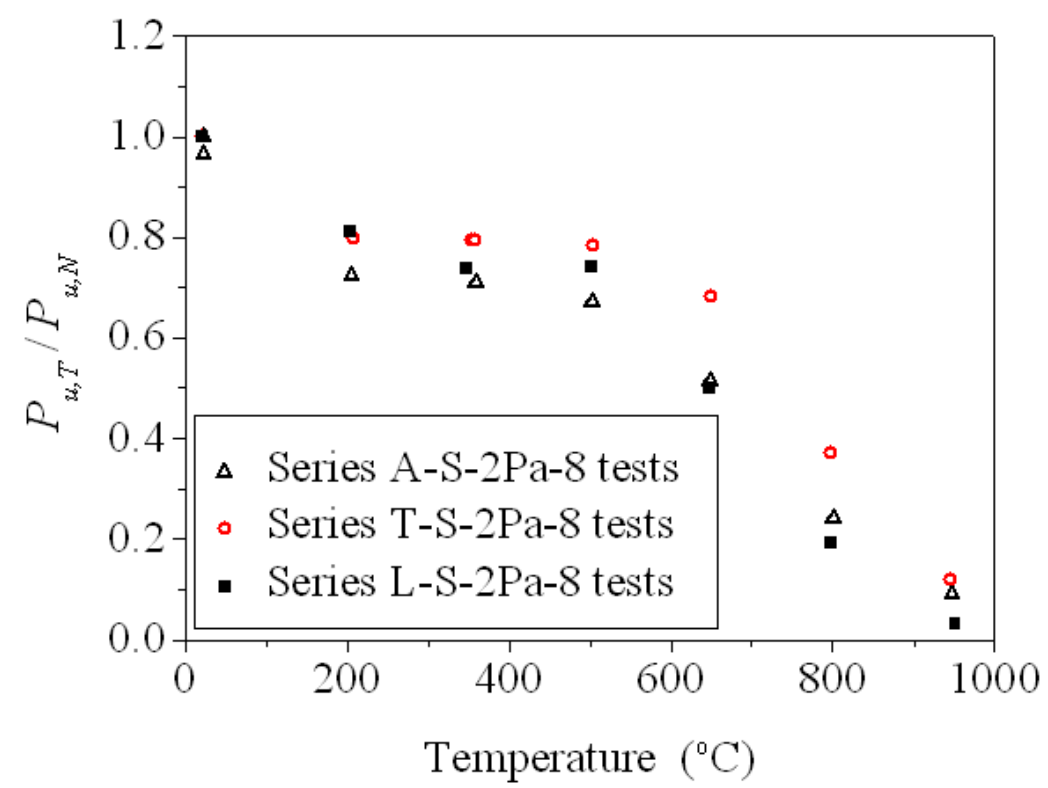

(b) Two-parallel bolted connections 


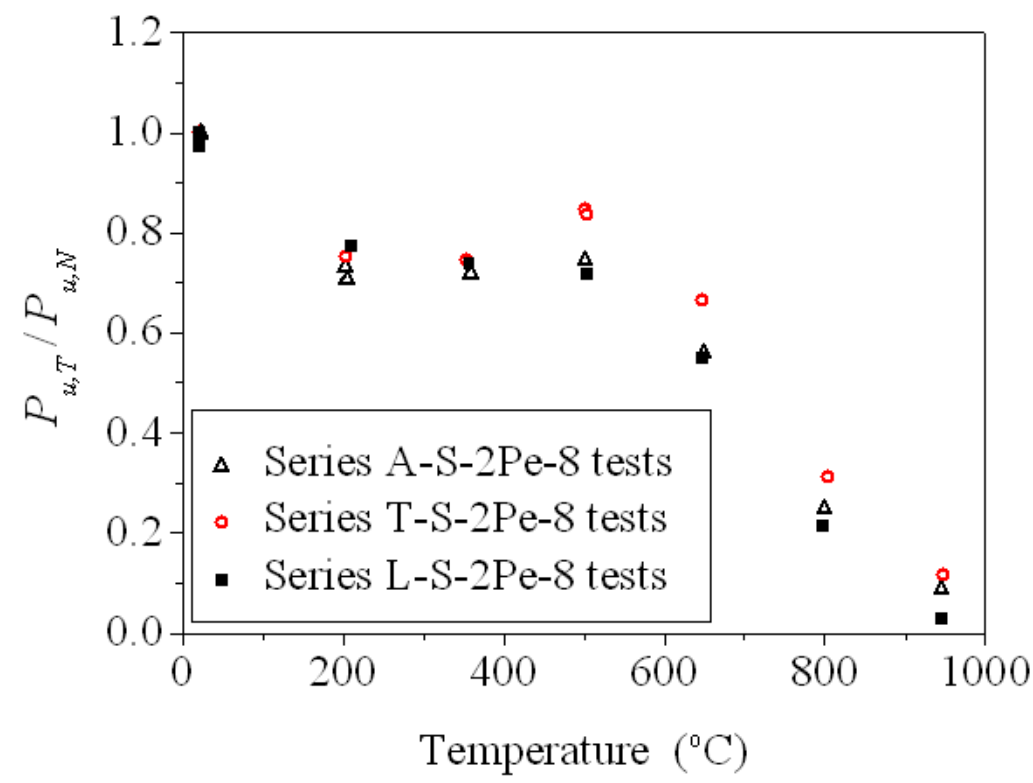

(c) Two-perpendicular bolted connections

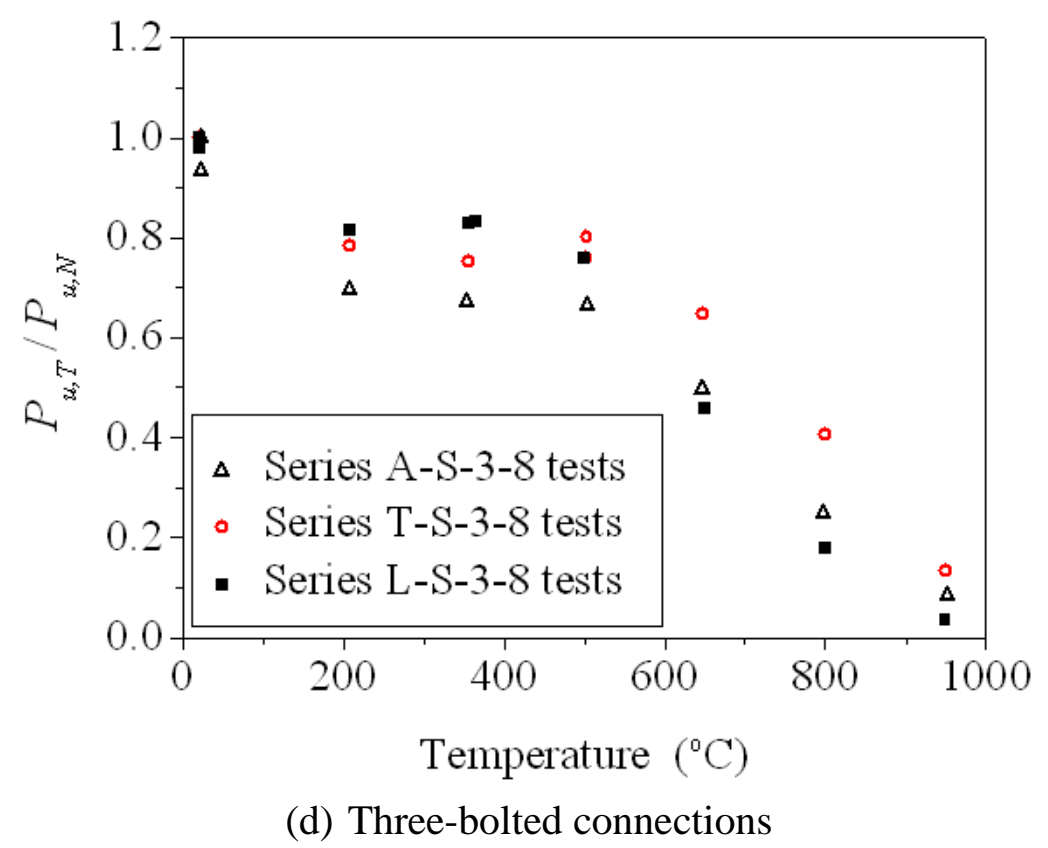




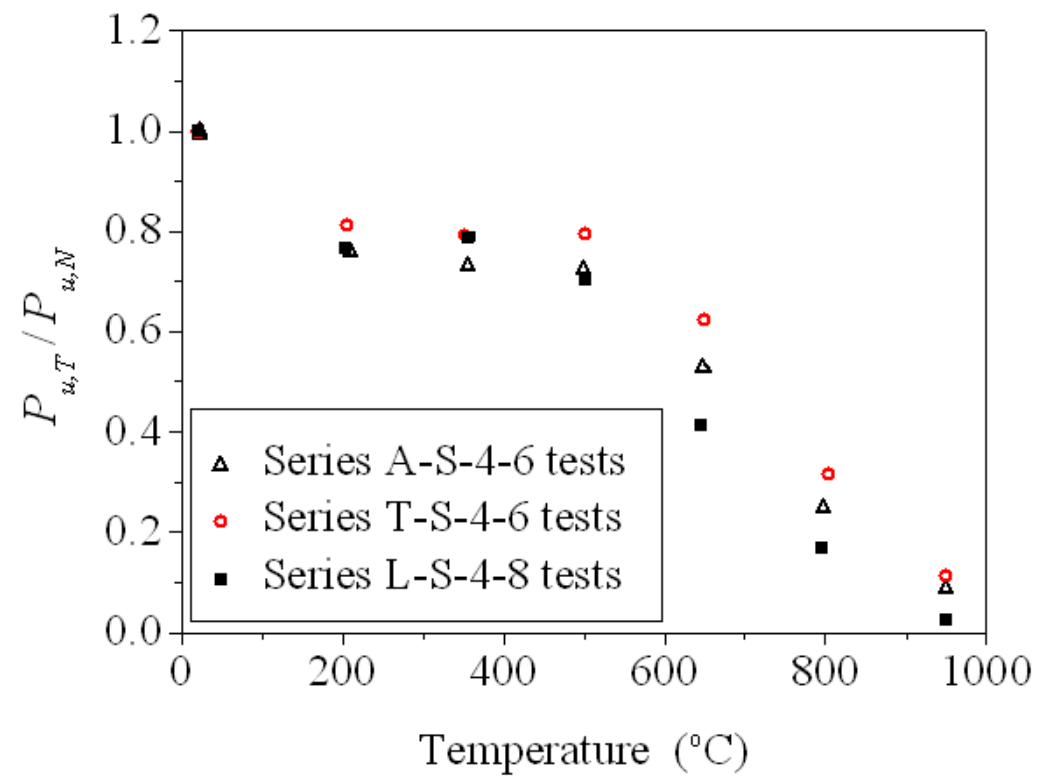

(e) Four-bolted connections

Fig. 5. Comparison of single shear bolted connection test results by steady state test method 


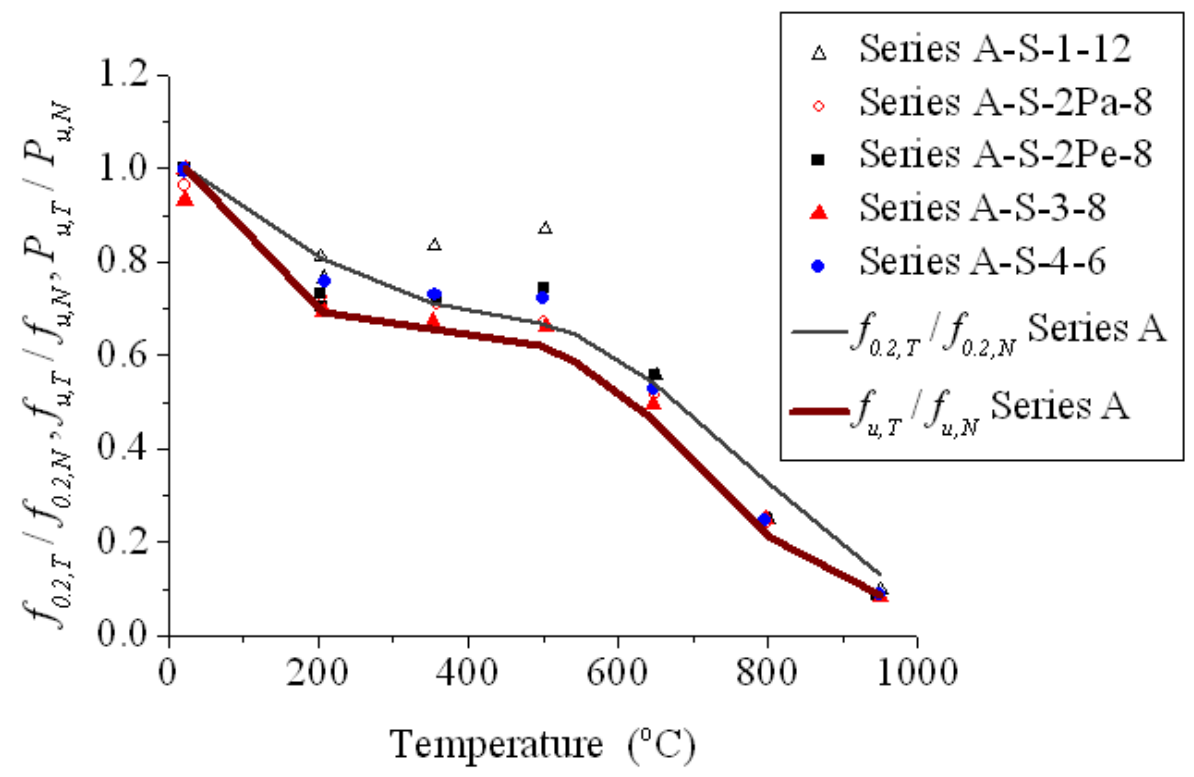

(a) Series A

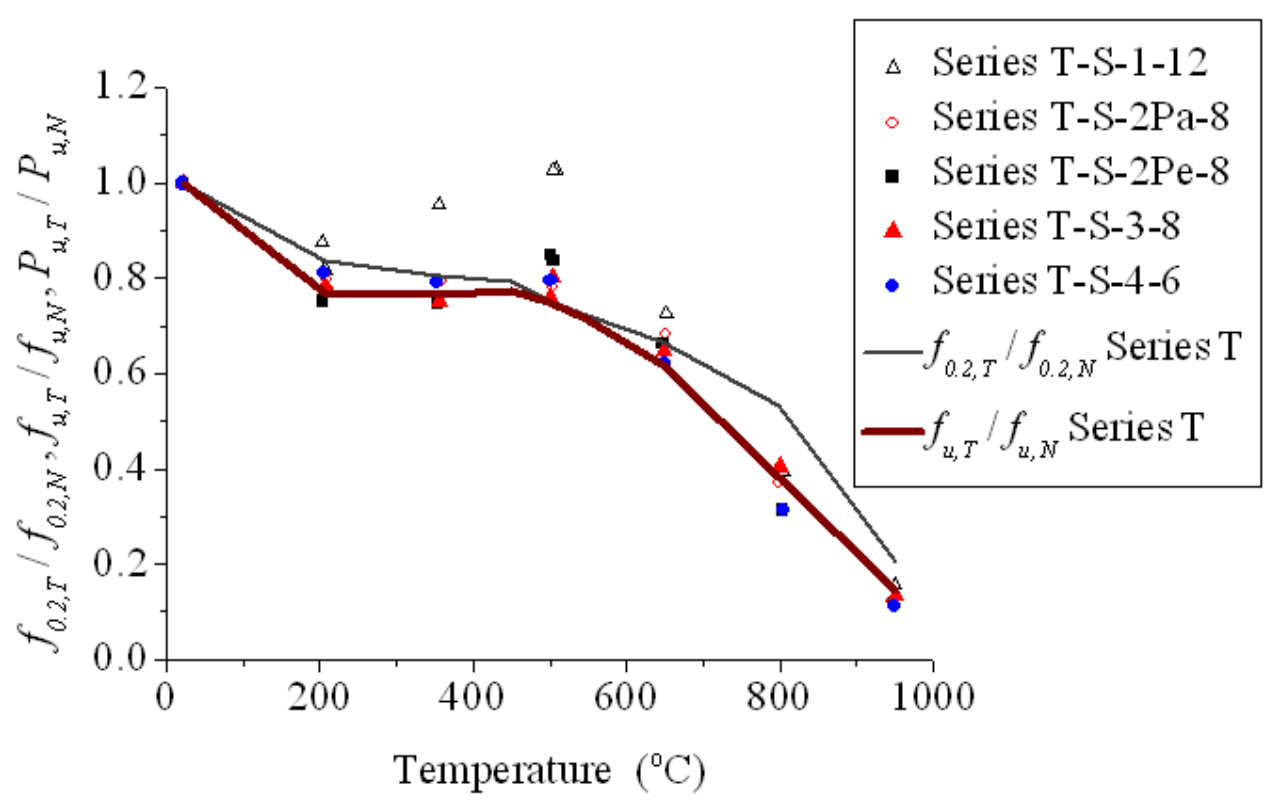

(b) Series $\mathrm{T}$ 


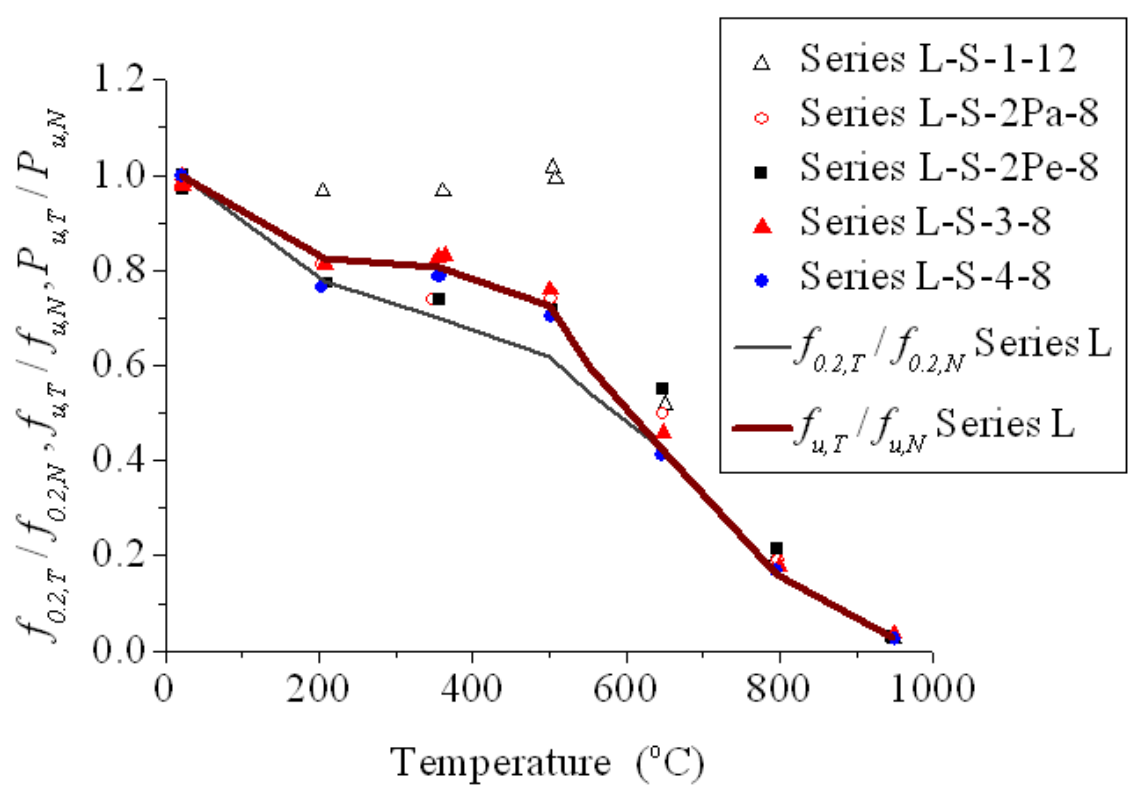

(c) Series L

Fig. 6. Comparison of connection test results with coupon test results 


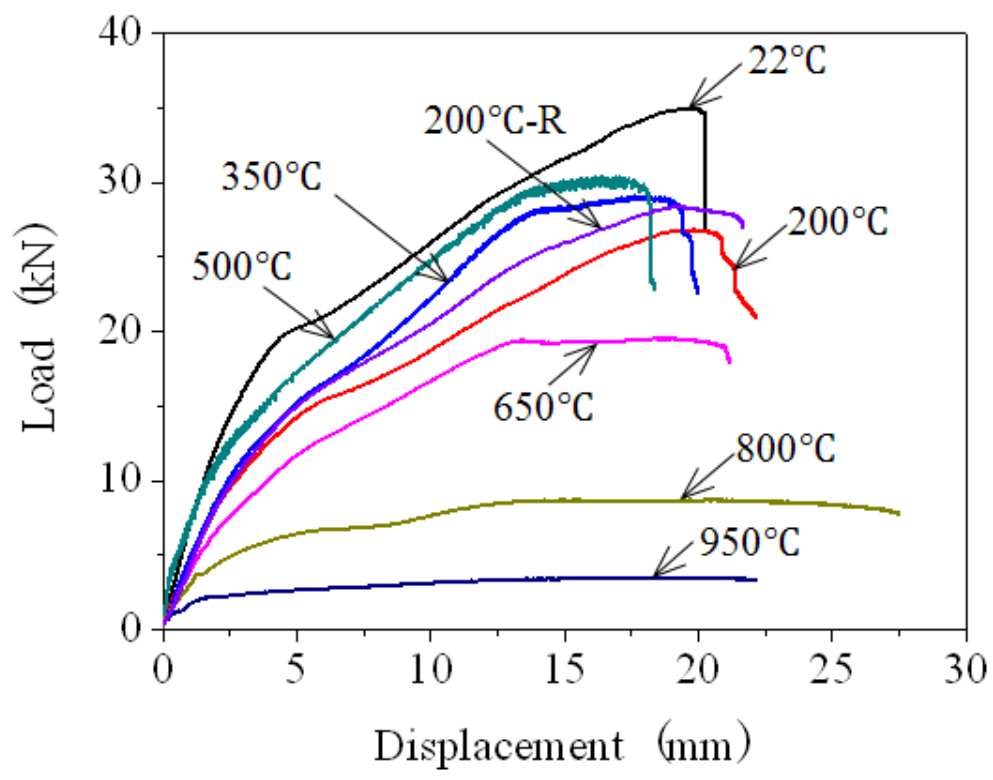

(a) Series A-S-1-12

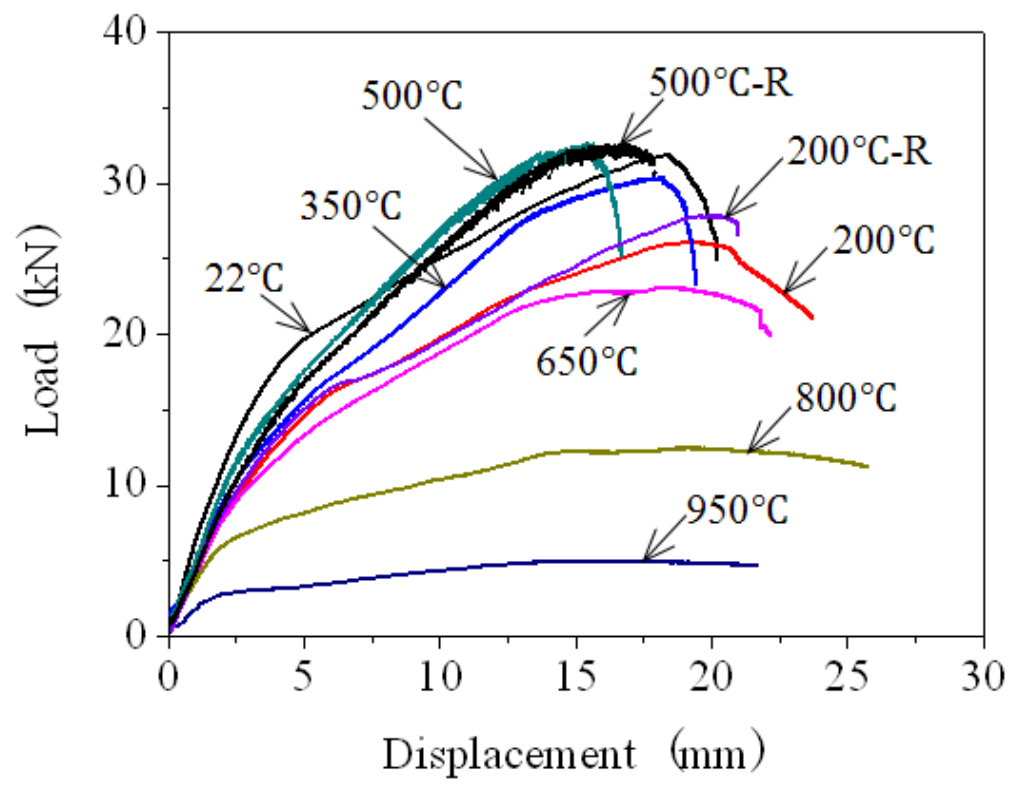

(b) Series T-S-1-12 


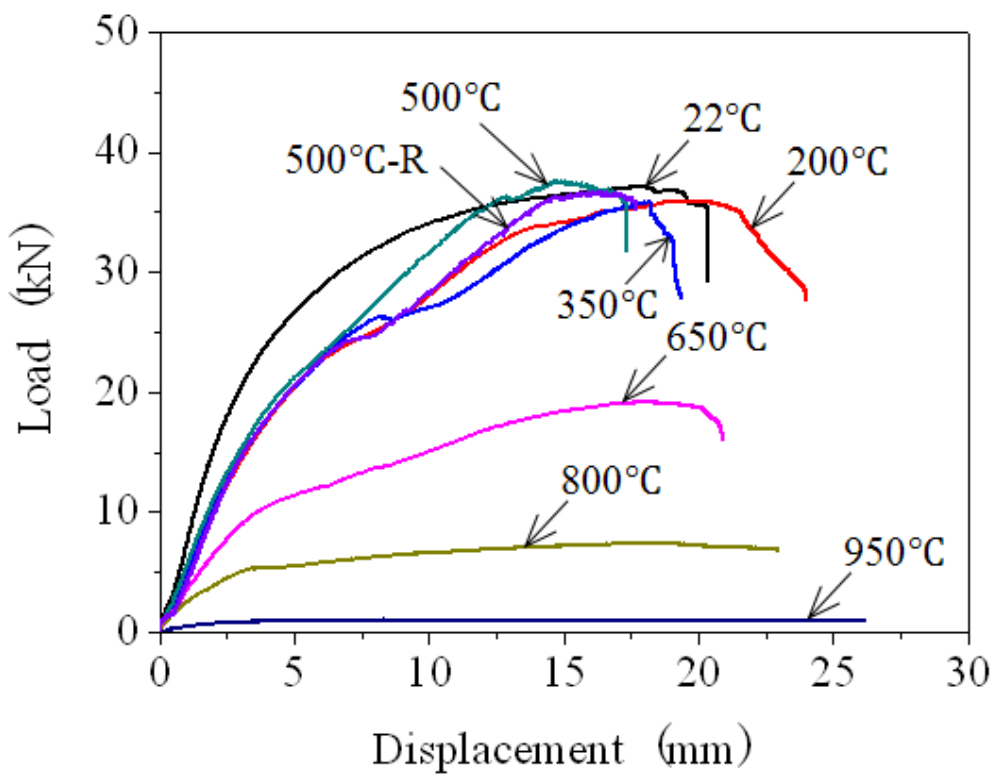

(c) Series L-S-1-12

Fig. 7. Test curves of single shear bolted connections at elevated temperatures 

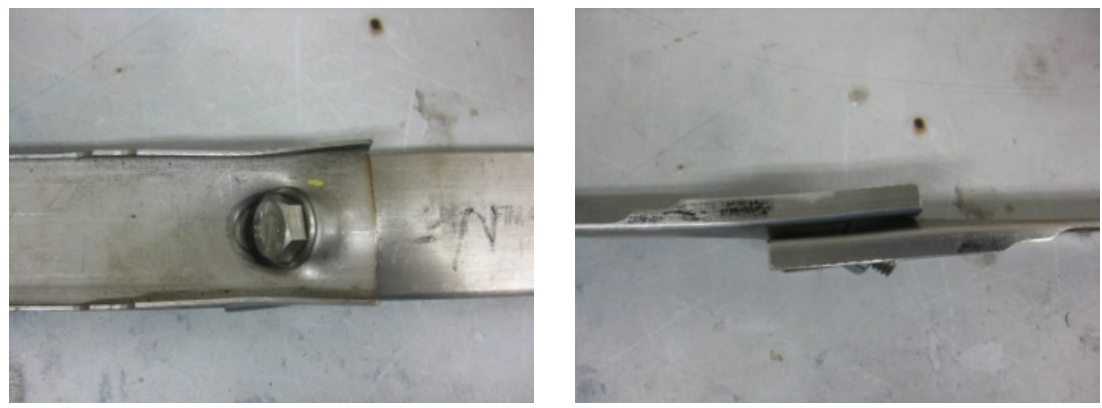

(a) $22{ }^{\circ} \mathrm{C}$
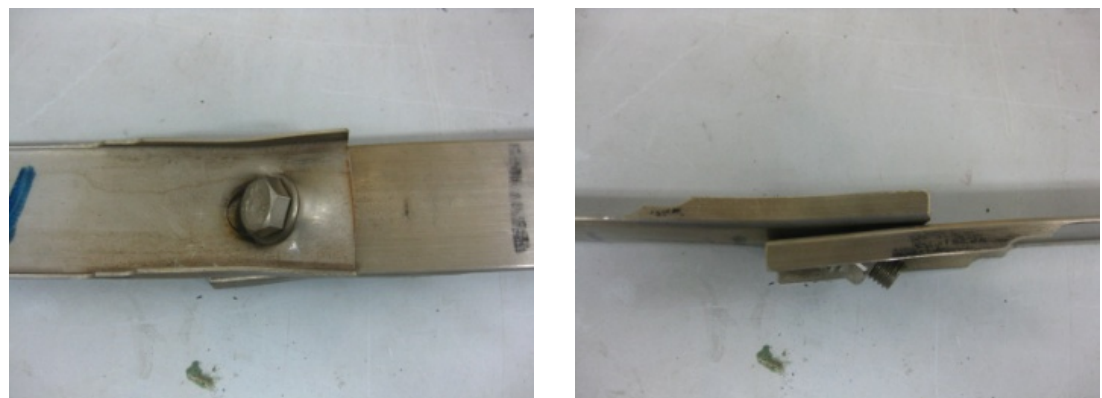

(b) $204^{\circ} \mathrm{C}$
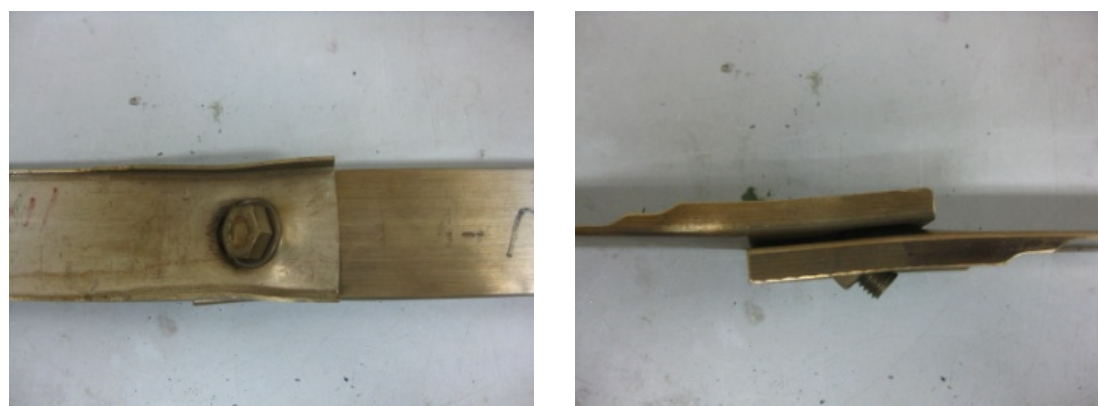

(c) $355^{\circ} \mathrm{C}$
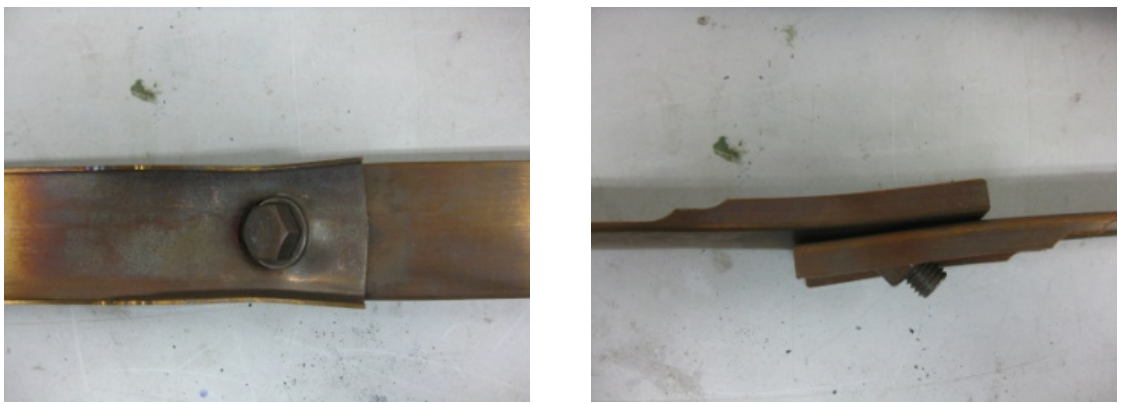

(d) $504{ }^{\circ} \mathrm{C}$ 

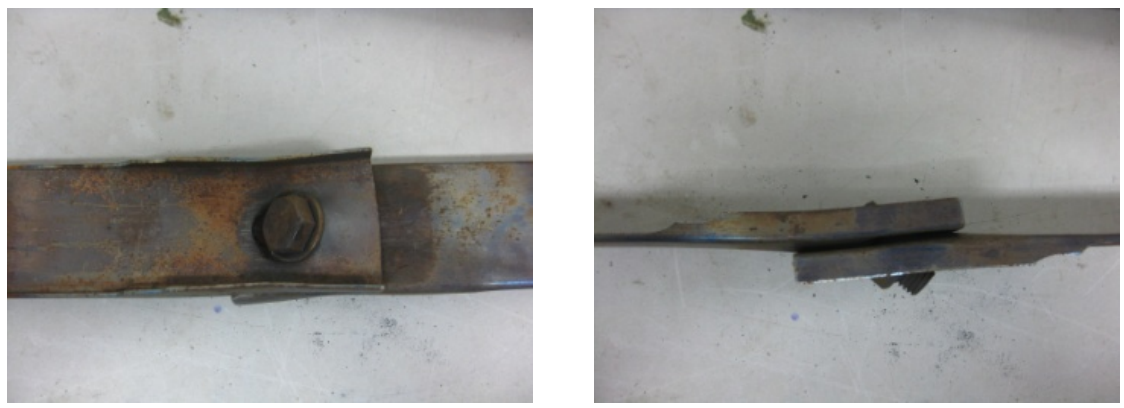

(e) $651^{\circ} \mathrm{C}$
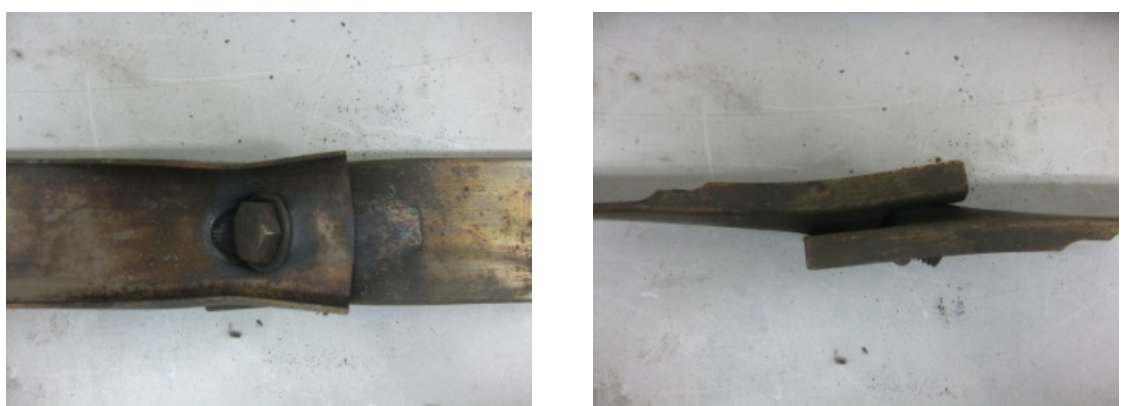

(f) $801^{\circ} \mathrm{C}$
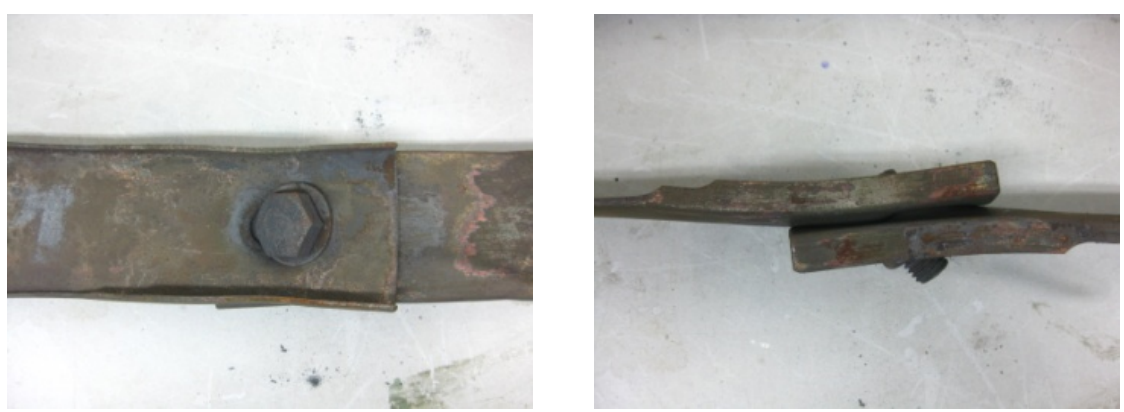

(g) $950{ }^{\circ} \mathrm{C}$

Fig. 8. Failure mode of specimens in Series A-S-1-12 at elevated temperatures 


\begin{tabular}{cccccccc}
\hline \hline \multirow{2}{*}{ Series } & Stainless steel type & $\begin{array}{c}E_{N} \\
\text { GPa }\end{array}$ & $\begin{array}{c}f_{0.2, N} \\
\mathrm{MPa}\end{array}$ & $\begin{array}{c}f_{u, N} \\
\mathrm{MPa}\end{array}$ & $\begin{array}{c}\varepsilon_{u, N} \\
\%\end{array}$ & $\begin{array}{c}\varepsilon_{f, N} \\
\%\end{array}$ & $n$ \\
\hline $\mathrm{A}$ & EN 1.4301 (AISI 304) & 199 & 474 & 759 & 45.2 & 52.6 & 5 \\
$\mathrm{~T}$ & EN 1.4571 (AISI 316Ti) & 199 & 463 & 677 & 38.8 & 46.8 & 7 \\
$\mathrm{~L}$ & EN 1.4162 (AISI S32101) & 200 & 724 & 862 & 19.7 & 36.8 & 7 \\
\hline \hline
\end{tabular}

Table 1: Coupon test results at room temperature [10]

\begin{tabular}{ccccccccc}
\hline \hline Nominal temperature $\left({ }^{\circ} \mathrm{C}\right)$ & 22 & 200 & 350 & 500 & 550 & 650 & 800 & 950 \\
Specimen temperature $\left({ }^{\circ} \mathrm{C}\right)$ & 22.0 & 205 & 351 & 496 & 544 & 648 & 800 & 950 \\
$E_{T} / E_{N}$ & 1.00 & 0.95 & 0.92 & 0.89 & 0.86 & 0.73 & 0.58 & 0.32 \\
$f_{0.2, T} / f_{0.2, N}$ & 1.00 & 0.81 & 0.71 & 0.67 & 0.65 & 0.54 & 0.33 & 0.13 \\
$f_{u, T} / f_{u, N}$ & 1.00 & 0.69 & 0.66 & 0.62 & 0.58 & 0.46 & 0.21 & 0.09 \\
$\varepsilon_{u, T} / \varepsilon_{u, N}$ & 1.00 & 0.41 & 0.36 & 0.47 & 0.36 & 0.38 & 0.02 & 0.01 \\
\hline \hline
\end{tabular}

(a) Series $\mathrm{A}$

\begin{tabular}{cccccccccc}
\hline \hline Nominal temperature $\left({ }^{\circ} \mathrm{C}\right)$ & 22 & 200 & 350 & 450 & 500 & 550 & 650 & 800 & 950 \\
Specimen temperature $\left({ }^{\circ} \mathrm{C}\right)$ & 22 & 206 & 356 & 449 & 498 & 548 & 645 & 800 & 950 \\
$E_{T} / E_{N}$ & 1.00 & 0.95 & 0.94 & 0.90 & 0.91 & 0.82 & 0.83 & 0.57 & 0.36 \\
$f_{0.2, T} / f_{0.2, N}$ & 1.00 & 0.84 & 0.80 & 0.79 & 0.75 & 0.72 & 0.67 & 0.53 & 0.20 \\
$f_{u, T} / f_{u, N}$ & 1.00 & 0.77 & 0.77 & 0.78 & 0.75 & 0.71 & 0.62 & 0.38 & 0.14 \\
$\varepsilon_{u, T} / \varepsilon_{u, N}$ & 1.00 & 0.52 & 0.48 & 0.49 & 0.45 & 0.40 & 0.42 & 0.03 & 0.01 \\
\hline \hline
\end{tabular}

(b) Series $\mathrm{T}$

\begin{tabular}{ccccccccc}
\hline \hline Nominal temperature $\left({ }^{\circ} \mathrm{C}\right)$ & 22 & 200 & 350 & 500 & 550 & 650 & 800 & 950 \\
Specimen temperature $\left({ }^{\circ} \mathrm{C}\right)$ & 22 & 206 & 356 & 501 & 553 & 652 & 795 & 948 \\
$E_{T} / E_{N}$ & 1.00 & 0.95 & 0.92 & 0.85 & 0.82 & 0.80 & 0.30 & 0.07 \\
$f_{0.2, T} / f_{0.2, N}$ & 1.00 & 0.78 & 0.70 & 0.62 & 0.54 & 0.42 & 0.16 & 0.02 \\
$f_{u, T} / f_{u, N}$ & 1.00 & 0.82 & 0.81 & 0.73 & 0.60 & 0.42 & 0.16 & 0.03 \\
$\varepsilon_{u, T} / \varepsilon_{u, N}$ & 1.00 & 0.97 & 0.52 & 0.68 & 0.54 & 0.51 & 0.08 & 0.14 \\
\hline \hline
\end{tabular}

(c) Series L

Table 2: Reduction factors of material properties obtained from coupon tests at elevated temperatures 


\begin{tabular}{|c|c|c|c|c|c|c|c|c|c|}
\hline \multirow{2}{*}{\multicolumn{3}{|c|}{ Temperature $\left({ }^{\circ} \mathrm{C}\right)$}} & \multirow{3}{*}{$\begin{array}{c}P_{u, N} \\
\text { or } \\
P_{u, T} \\
(\mathrm{kN}) \\
\end{array}$} & \multirow{3}{*}{$P_{u, T} / P_{u, N}$} & \multirow{3}{*}{$\begin{array}{c}P_{u, N} / P_{A S C E} \\
\quad \text { or } \\
P_{u, T} / P_{A S C E}\end{array}$} & \multirow{3}{*}{$\begin{array}{c}P_{u, N} / P_{E C} \\
\quad \text { or } \\
P_{u, T} / P_{E C}\end{array}$} & \multicolumn{3}{|c|}{ Failure mode } \\
\hline & & & & & & & \multirow{2}{*}{$\begin{array}{c}\text { ASCE } \\
\text { and } \\
\text { AS/NZS }\end{array}$} & \multirow{2}{*}{ EC } & \multirow{2}{*}{ Test } \\
\hline Nominal & Coupon & Specimen & & & & & & & \\
\hline 22 & 22 & 22 & 34.9 & 1.00 & 1.44 & 1.90 & NS & B & B \\
\hline \multirow[t]{2}{*}{200} & 205 & 207 & 26.7 & 0.77 & 1.61 & 2.01 & --- & --- & B \\
\hline & & 204 & 28.3 & 0.81 & 1.71 & 2.13 & --- & --- & B \\
\hline 350 & 351 & 355 & 29.1 & 0.83 & 1.85 & 2.36 & --- & --- & B \\
\hline 500 & 496 & 504 & 30.4 & 0.87 & 2.05 & 2.63 & --- & --- & B \\
\hline 650 & 648 & 651 & 19.5 & 0.56 & 1.76 & 2.19 & --- & --- & B \\
\hline 800 & 800 & 801 & 8.7 & 0.25 & 1.69 & 2.03 & --- & --- & B \\
\hline \multirow[t]{3}{*}{950} & 950 & 950 & 3.4 & 0.10 & 1.66 & 1.99 & --- & --- & $\mathrm{B}$ \\
\hline & & & & Mean & 1.72 & 2.16 & & & \\
\hline & & & & $\mathrm{COV}$ & 0.104 & 0.110 & & & \\
\hline
\end{tabular}

Note: $\mathrm{B}=$ Bearing failure; NS = Net section tension failure.

(a) Series A-S-1-12 


\begin{tabular}{|c|c|c|c|c|c|c|c|c|c|}
\hline \multirow{2}{*}{\multicolumn{3}{|c|}{ Temperature $\left({ }^{\circ} \mathrm{C}\right)$}} & \multirow{3}{*}{$\begin{array}{c}P_{u, N} \\
\text { or } \\
P_{u, T} \\
(\mathrm{kN})\end{array}$} & \multirow{3}{*}{$P_{u, T} / P_{u, N}$} & \multirow{3}{*}{$\begin{array}{c}P_{u, N} / P_{A S C E} \\
\quad \text { or } \\
P_{u, T} / P_{A S C E}\end{array}$} & \multirow{3}{*}{$\begin{array}{c}P_{u, N} / P_{E C} \\
\quad \text { or } \\
P_{u, T} / P_{E C}\end{array}$} & \multicolumn{3}{|c|}{ Failure mode } \\
\hline & & & & & & & \multirow{2}{*}{$\begin{array}{c}\text { ASCE } \\
\text { and } \\
\text { AS/NZS }\end{array}$} & \multirow[b]{2}{*}{ EC } & \multirow[b]{2}{*}{ Test } \\
\hline Nominal & Coupon & Specimen & & & & & & & \\
\hline 22 & 22 & 22 & 31.8 & 1.00 & 1.48 & 1.88 & NS & B & B \\
\hline \multirow[t]{2}{*}{200} & 206 & 207 & 26.0 & 0.82 & 1.59 & 1.95 & --- & --- & B \\
\hline & & 203 & 27.8 & 0.87 & 1.70 & 2.09 & --- & --- & B \\
\hline 350 & 356 & 355 & 30.4 & 0.96 & 1.86 & 2.33 & --- & --- & B \\
\hline \multirow[t]{2}{*}{500} & 498 & 508 & 32.7 & 1.03 & 2.05 & 2.61 & --- & --- & B \\
\hline & & 505 & 32.6 & 1.03 & 2.04 & 2.60 & --- & --- & B \\
\hline 650 & 645 & 652 & 23.1 & 0.73 & 1.74 & 2.16 & --- & --- & B \\
\hline 800 & 800 & 803 & 12.5 & 0.39 & 1.54 & 1.84 & --- & --- & B \\
\hline \multirow[t]{3}{*}{950} & 950 & 950 & 5.0 & 0.16 & 1.63 & 1.96 & --- & --- & B \\
\hline & & & & Mean & 1.74 & 2.16 & & & \\
\hline & & & & $\mathrm{COV}$ & 0.119 & 0.137 & & & \\
\hline
\end{tabular}

Note: $\mathrm{B}=$ Bearing failure; NS = Net section tension failure.

(b) Series T-S-1-12 


\begin{tabular}{|c|c|c|c|c|c|c|c|c|c|}
\hline \multirow{2}{*}{\multicolumn{3}{|c|}{ Temperature $\left({ }^{\circ} \mathrm{C}\right)$}} & \multirow{3}{*}{$\begin{array}{c}P_{u, N} \\
\text { or } \\
P_{u, T} \\
(\mathrm{kN})\end{array}$} & \multirow{3}{*}{$P_{u, T} / P_{u, N}$} & \multirow{3}{*}{$\begin{array}{c}P_{u, N} / P_{A S C E} \\
\quad \text { or } \\
P_{u, T} / P_{A S C E}\end{array}$} & \multirow{3}{*}{$\begin{array}{c}P_{u, N} / P_{E C} \\
\quad \text { or } \\
P_{u, T} / P_{E C}\end{array}$} & \multicolumn{3}{|c|}{ Failure mode } \\
\hline & & & & & & & \multirow{2}{*}{$\begin{array}{c}\text { ASCE } \\
\text { and } \\
\text { AS/NZS }\end{array}$} & \multirow[b]{2}{*}{$\mathrm{EC}$} & \multirow[b]{2}{*}{ Test } \\
\hline Nominal & Coupon & Specimen & & & & & & & \\
\hline 22 & 22 & 22 & 37.1 & 1.00 & 1.33 & 1.59 & NS & $\mathrm{B}$ & $\mathrm{B}$ \\
\hline 200 & 206 & 205 & 35.9 & 0.97 & 1.60 & 1.93 & --- & --- & B \\
\hline 350 & 356 & 361 & 35.9 & 0.97 & 1.64 & 2.03 & --- & --- & B \\
\hline \multirow[t]{2}{*}{500} & 501 & 505 & 37.7 & 1.02 & 1.91 & 2.39 & --- & --- & B \\
\hline & & 508 & 36.8 & 0.99 & 1.86 & 2.33 & --- & --- & B \\
\hline 650 & 652 & 652 & 19.2 & 0.52 & 1.70 & 2.04 & --- & --- & B \\
\hline 800 & 795 & 796 & 7.4 & 0.20 & 1.70 & 2.04 & --- & --- & B \\
\hline \multirow[t]{3}{*}{950} & 948 & 950 & 1.0 & 0.03 & 1.27 & 1.59 & --- & --- & B \\
\hline & & & & Mean & 1.63 & 1.99 & & & \\
\hline & & & & $\mathrm{COV}$ & 0.140 & 0.148 & & & \\
\hline
\end{tabular}

Note: $\mathrm{B}$ = Bearing failure; NS = Net section tension failure.

(c) Series L-S-1-12

Table 3: Comparison of test results with predicted values for single shear one-bolted connections 


\begin{tabular}{|c|c|c|c|c|c|c|c|c|c|}
\hline \multirow{2}{*}{\multicolumn{3}{|c|}{ Temperature $\left({ }^{\circ} \mathrm{C}\right)$}} & \multirow{3}{*}{$\begin{array}{c}P_{u, N} \\
\text { or } \\
P_{u, T} \\
(\mathrm{kN})\end{array}$} & \multirow{3}{*}{$P_{u, T} / P_{u, N}$} & \multirow{3}{*}{$\begin{array}{l}P_{u, N} / P_{A S C E} \\
\quad \text { or } \\
P_{u, T} / P_{A S C E}\end{array}$} & \multirow{3}{*}{$\begin{array}{c}P_{u, N} / P_{E C} \\
\quad \text { or } \\
P_{u, T} / P_{E C}\end{array}$} & \multicolumn{3}{|c|}{ Failure mode } \\
\hline & & & & & & & \multirow{2}{*}{$\begin{array}{c}\text { ASCE } \\
\text { and } \\
\text { AS/NZS }\end{array}$} & \multirow{2}{*}{ EC } & \multirow{2}{*}{ Test } \\
\hline Nominal & Coupon & Specimen & & & & & & & \\
\hline \multirow[t]{2}{*}{22} & 22 & 22 & 38.9 & 1.00 & 1.39 & 1.14 & NS & NS & B \\
\hline & & 22 & 37.5 & 0.96 & 1.33 & 1.09 & NS & NS & B \\
\hline 200 & 205 & 206 & 28.1 & 0.72 & 1.27 & 1.09 & --- & --- & B \\
\hline 350 & 351 & 359 & 27.6 & 0.71 & 1.36 & 1.15 & --- & --- & B \\
\hline 500 & 496 & 502 & 26.1 & 0.67 & 1.38 & 1.16 & --- & --- & B \\
\hline 650 & 648 & 648 & 20.0 & 0.51 & 1.36 & 1.16 & --- & --- & B \\
\hline 800 & 800 & 800 & 9.4 & 0.24 & 1.38 & 1.18 & --- & --- & B \\
\hline \multirow[t]{3}{*}{950} & 950 & 948 & 3.5 & 0.09 & 1.29 & 1.10 & --- & --- & B \\
\hline & & & & Mean & 1.35 & 1.13 & & & \\
\hline & & & & $\mathrm{COV}$ & 0.033 & 0.031 & & & \\
\hline
\end{tabular}

Note: $\mathrm{B}=$ Bearing failure; NS = Net section tension failure.

(a) Series A-S-2Pa-8 


\begin{tabular}{|c|c|c|c|c|c|c|c|c|c|}
\hline \multirow{2}{*}{\multicolumn{3}{|c|}{ Temperature $\left({ }^{\circ} \mathrm{C}\right)$}} & \multirow{3}{*}{$\begin{array}{c}P_{u, N} \\
\text { or } \\
P_{u, T} \\
(\mathrm{kN})\end{array}$} & \multirow{3}{*}{$P_{u, T} / P_{u, N}$} & \multirow{3}{*}{$\begin{array}{c}P_{u, N} / P_{A S C E} \\
\quad \text { or } \\
P_{u, T} / P_{A S C E}\end{array}$} & \multirow{3}{*}{$\begin{array}{c}P_{u, N} / P_{E C} \\
\quad \text { or } \\
P_{u, T} / P_{E C}\end{array}$} & \multicolumn{3}{|c|}{ Failure mode } \\
\hline & & & & & & & \multirow{2}{*}{$\begin{array}{c}\text { ASCE } \\
\text { and } \\
\text { AS/NZS }\end{array}$} & \multirow{2}{*}{ EC } & \multirow{2}{*}{ Test } \\
\hline Nominal & Coupon & Specimen & & & & & & & \\
\hline 22 & 22 & 22 & 36.7 & 1.00 & 1.33 & 1.13 & NS & B & B \\
\hline 200 & 206 & 208 & 29.3 & 0.80 & 1.34 & 1.15 & --- & --- & B \\
\hline \multirow[t]{2}{*}{350} & 356 & 354 & 29.2 & 0.80 & 1.34 & 1.15 & --- & --- & B \\
\hline & & 359 & 29.1 & 0.79 & 1.34 & 1.14 & --- & --- & B \\
\hline 500 & 498 & 504 & 28.7 & 0.78 & 1.38 & 1.18 & --- & --- & B \\
\hline 650 & 645 & 651 & 25.0 & 0.68 & 1.42 & 1.21 & --- & --- & B \\
\hline 800 & 800 & 798 & 13.6 & 0.37 & 1.26 & 1.07 & --- & --- & $\mathrm{B}+\mathrm{BS}$ \\
\hline \multirow[t]{3}{*}{950} & 950 & 946 & 4.4 & 0.12 & 1.08 & 0.92 & --- & --- & $\mathrm{B}+\mathrm{BS}$ \\
\hline & & & & Mean & 1.31 & 1.12 & & & \\
\hline & & & & $\mathrm{COV}$ & 0.079 & 0.080 & & & \\
\hline
\end{tabular}

Note: $\mathrm{B}$ = Bearing failure; NS = Net section tension failure; BS = Bolt shear failure.

(b) Series T-S-2Pa-8 


\begin{tabular}{|c|c|c|c|c|c|c|c|c|c|}
\hline \multirow{2}{*}{\multicolumn{3}{|c|}{ Temperature $\left({ }^{\circ} \mathrm{C}\right)$}} & \multirow{3}{*}{$\begin{array}{c}P_{u, N} \\
\text { or } \\
P_{u, T} \\
(\mathrm{kN})\end{array}$} & \multirow{3}{*}{$P_{u, T} / P_{u, N}$} & \multirow{3}{*}{$\begin{array}{c}P_{u, N} / P_{A S C E} \\
\quad \text { or } \\
P_{u, T} / P_{A S C E}\end{array}$} & \multirow{3}{*}{$\begin{array}{c}P_{u, N} / P_{E C} \\
\quad \text { or } \\
P_{u, T} / P_{E C}\end{array}$} & \multicolumn{3}{|c|}{ Failure mode } \\
\hline & & & & & & & \multirow{2}{*}{$\begin{array}{c}\text { ASCE } \\
\text { and } \\
\text { AS/NZS }\end{array}$} & \multirow[b]{2}{*}{$\mathrm{EC}$} & \multirow[b]{2}{*}{ Test } \\
\hline Nominal & Coupon & Specimen & & & & & & & \\
\hline \multirow[t]{2}{*}{22} & 22 & 22 & 42.8 & 1.00 & 1.18 & 1.00 & NS & NS & $\mathrm{B}+\mathrm{BS}$ \\
\hline & & 22 & 42.8 & 1.00 & 1.20 & 1.03 & NS & NS & $\mathrm{B}+\mathrm{BS}$ \\
\hline 200 & 206 & 204 & 34.8 & 0.81 & 1.17 & 1.00 & --- & --- & $\mathrm{B}+\mathrm{BS}$ \\
\hline 350 & 356 & 348 & 31.6 & 0.74 & 1.08 & 0.93 & --- & --- & $\mathrm{B}+\mathrm{BS}$ \\
\hline 500 & 501 & 502 & 31.7 & 0.74 & 1.21 & 1.03 & --- & --- & $\mathrm{B}+\mathrm{BS}$ \\
\hline 650 & 652 & 647 & 21.4 & 0.50 & 1.43 & 1.22 & --- & --- & B \\
\hline 800 & 795 & 798 & 8.2 & 0.19 & 1.42 & 1.21 & --- & --- & B \\
\hline \multirow[t]{3}{*}{950} & 948 & 951 & 1.3 & 0.03 & 1.24 & 1.06 & --- & --- & B \\
\hline & & & & Mean & 1.24 & 1.06 & & & \\
\hline & & & & $\mathrm{COV}$ & 0.099 & 0.097 & & & \\
\hline
\end{tabular}

Note: $\mathrm{B}$ = Bearing failure; NS = Net section tension failure; BS = Bolt shear failure.

\section{(c) Series L-S-2Pa-8}

Table 4: Comparison of test results with predicted values for single shear two-parallel bolted connections 


\begin{tabular}{|c|c|c|c|c|c|c|c|c|c|}
\hline \multicolumn{3}{|c|}{ Temperature $\left({ }^{\circ} \mathrm{C}\right)$} & \multirow{2}{*}{$\begin{array}{c}P_{u, N} \\
\text { or } \\
P_{u, T} \\
(\mathrm{kN})\end{array}$} & \multirow{2}{*}{$P_{u, T} / P_{u, N}$} & \multirow{2}{*}{$\begin{array}{c}P_{u, N} / P_{A S C E} \\
\quad \text { or } \\
P_{u, T} / P_{A S C E}\end{array}$} & \multirow{2}{*}{$\begin{array}{c}P_{u, N} / P_{E C} \\
\quad \text { or } \\
P_{u, T} / P_{E C}\end{array}$} & \multicolumn{3}{|c|}{ Failure mode } \\
\hline Nominal & Coupon & Specimen & & & & & $\begin{array}{c}\text { and } \\
\text { AS/NZS }\end{array}$ & EC & Test \\
\hline \multirow[t]{2}{*}{22} & 22 & 22 & 41.8 & 1.00 & 1.87 & 1.71 & NS & B & B \\
\hline & & 22 & 41.6 & 1.00 & 1.91 & 1.74 & NS & B & B \\
\hline \multirow[t]{2}{*}{200} & 205 & 204 & 29.5 & 0.71 & 1.65 & 1.66 & --- & --- & B \\
\hline & & 203 & 30.6 & 0.73 & 1.71 & 1.72 & --- & --- & B \\
\hline 350 & 351 & 359 & 30.0 & 0.72 & 1.90 & 1.83 & --- & --- & B \\
\hline 500 & 496 & 501 & 31.1 & 0.74 & 2.10 & 2.01 & --- & --- & B \\
\hline 650 & 648 & 650 & 23.4 & 0.56 & 1.95 & 1.97 & --- & --- & B \\
\hline 800 & 800 & 798 & 10.4 & 0.25 & 1.50 & 1.82 & --- & --- & B \\
\hline \multirow[t]{3}{*}{950} & 950 & 945 & 3.7 & 0.09 & 1.34 & 1.62 & --- & --- & $\mathrm{B}$ \\
\hline & & & & Mean & 1.77 & 1.79 & & & \\
\hline & & & & $\mathrm{COV}$ & 0.136 & 0.075 & & & \\
\hline
\end{tabular}

Note: $\mathrm{B}$ = Bearing failure; NS = Net section tension failure.

(a) Series A-S-2Pe-8 


\begin{tabular}{|c|c|c|c|c|c|c|c|c|c|}
\hline \multirow{2}{*}{\multicolumn{3}{|c|}{ Temperature $\left({ }^{\circ} \mathrm{C}\right)$}} & \multirow{3}{*}{$\begin{array}{c}P_{u, N} \\
o r \\
P_{u, T} \\
(\mathrm{kN})\end{array}$} & \multirow{3}{*}{$P_{u, T} / P_{u, N}$} & \multirow{3}{*}{$\begin{array}{c}P_{u, N} / P_{A S C E} \\
\quad \text { or } \\
P_{u, T} / P_{A S C E}\end{array}$} & \multirow{3}{*}{$\begin{array}{c}P_{u, N} / P_{E C} \\
\quad \text { or } \\
P_{u, T} / P_{E C}\end{array}$} & \multicolumn{3}{|c|}{ Failure mode } \\
\hline & & & & & & & \multirow{2}{*}{$\begin{array}{c}\text { ASCE } \\
\text { and } \\
\text { AS/NZS }\end{array}$} & \multirow{2}{*}{$\mathrm{EC}$} & \multirow{2}{*}{ Test } \\
\hline Nominal & Coupon & Specimen & & & & & & & \\
\hline 22 & 22 & 22 & 38.7 & 1.00 & 1.82 & 1.76 & NS & B & B \\
\hline 200 & 206 & 204 & 29.1 & 0.75 & 1.61 & 1.64 & --- & --- & B \\
\hline 350 & 356 & 355 & 28.8 & 0.74 & 1.66 & 1.65 & --- & --- & B \\
\hline \multirow[t]{2}{*}{500} & 498 & 501 & 32.8 & 0.85 & 2.02 & 1.96 & --- & --- & B \\
\hline & & 505 & 32.4 & 0.84 & 1.99 & 1.94 & --- & --- & B \\
\hline 650 & 645 & 647 & 25.7 & 0.66 & 1.79 & 1.81 & --- & --- & $\mathrm{B}+\mathrm{BS}$ \\
\hline 800 & 800 & 804 & 12.1 & 0.31 & 1.10 & 1.34 & --- & --- & $\mathrm{B}+\mathrm{BS}$ \\
\hline \multirow[t]{3}{*}{950} & 950 & 948 & 4.5 & 0.12 & 1.09 & 1.32 & --- & --- & $\mathrm{B}+\mathrm{BS}$ \\
\hline & & & & Mean & 1.64 & 1.68 & & & \\
\hline & & & & $\mathrm{COV}$ & 0.221 & 0.145 & & & \\
\hline
\end{tabular}

Note: $\mathrm{B}$ = Bearing failure; NS = Net section tension failure; BS = Bolt shear failure.

(b) Series T-S-2Pe-8 


\begin{tabular}{|c|c|c|c|c|c|c|c|c|c|}
\hline \multirow{2}{*}{\multicolumn{3}{|c|}{ Temperature $\left({ }^{\circ} \mathrm{C}\right)$}} & \multirow{3}{*}{$\begin{array}{c}P_{u, N} \\
\text { or } \\
P_{u, T} \\
(\mathrm{kN})\end{array}$} & \multirow{3}{*}{$P_{u, T} / P_{u, N}$} & \multirow{3}{*}{$\begin{array}{c}P_{u, N} / P_{A S C E} \\
\quad \text { or } \\
P_{u, T} / P_{A S C E}\end{array}$} & \multirow{3}{*}{$\begin{array}{c}P_{u, N} / P_{E C} \\
\quad \text { or } \\
P_{u, T} / P_{E C}\end{array}$} & \multicolumn{3}{|c|}{$\begin{array}{ll}\text { Failure mode } \\
\end{array}$} \\
\hline & & & & & & & ASCE & & \\
\hline Nominal & Coupon & Specimen & & & & & $\begin{array}{c}\text { and } \\
\text { AS/NZS }\end{array}$ & EC & Test \\
\hline \multirow[t]{2}{*}{22} & \multirow[t]{2}{*}{22} & 22 & 43.4 & 1.00 & 1.25 & 1.40 & NS & B & $\mathrm{B}+\mathrm{BS}$ \\
\hline & & 22 & 42.2 & 0.97 & 1.29 & 1.45 & NS & B & $\mathrm{B}+\mathrm{BS}$ \\
\hline 200 & 206 & 211 & 33.6 & 0.77 & 1.28 & 1.35 & --- & --- & $\mathrm{B}+\mathrm{BS}$ \\
\hline 350 & 356 & 358 & 32.1 & 0.74 & 1.35 & 1.36 & --- & --- & $\mathrm{B}+\mathrm{BS}$ \\
\hline 500 & 501 & 504 & 31.1 & 0.72 & 1.49 & 1.48 & --- & --- & $\mathrm{B}+\mathrm{BS}$ \\
\hline 650 & 652 & 649 & 23.9 & 0.55 & 1.68 & 1.91 & --- & --- & B \\
\hline 800 & 795 & 797 & 9.3 & 0.21 & 1.67 & 1.92 & --- & --- & B \\
\hline \multirow[t]{3}{*}{950} & 948 & 945 & 1.3 & 0.03 & 1.55 & 1.55 & --- & --- & B \\
\hline & & & & Mean & 1.45 & 1.55 & & & \\
\hline & & & & $\mathrm{COV}$ & 0.122 & 0.150 & & & \\
\hline
\end{tabular}

Note: $\mathrm{B}$ = Bearing failure; NS = Net section tension failure; BS = Bolt shear failure.

(c) Series L-S-2Pe-8

Table 5: Comparison of test results with predicted values for single shear two-perpendicular bolted connections 


\begin{tabular}{|c|c|c|c|c|c|c|c|c|c|}
\hline \multirow{2}{*}{\multicolumn{3}{|c|}{ Temperature $\left({ }^{\circ} \mathrm{C}\right)$}} & \multirow{3}{*}{$\begin{array}{c}P_{u, N} \\
\text { or } \\
P_{u, T} \\
(\mathrm{kN})\end{array}$} & \multirow{3}{*}{$P_{u, T} / P_{u, N}$} & \multirow{3}{*}{$\begin{array}{c}P_{u, N} / P_{A S C E} \\
\quad \text { or } \\
P_{u, T} / P_{A S C E}\end{array}$} & \multirow{3}{*}{$\begin{array}{c}P_{u, N} / P_{E C} \\
\quad \text { or } \\
P_{u, T} / P_{E C}\end{array}$} & \multicolumn{3}{|c|}{ Failure mode } \\
\hline & & & & & & & ASCE & & \\
\hline Nominal & Coupon & Specimen & & & & & $\begin{array}{c}\text { and } \\
\text { AS/NZS }\end{array}$ & EC & Test \\
\hline \multirow[t]{2}{*}{22} & 22 & 22 & 45.4 & 1.00 & 2.03 & 1.29 & NS & NS & $\mathrm{B}+\mathrm{NS}$ \\
\hline & & 22 & 42.4 & 0.93 & 1.93 & 1.23 & NS & NS & $\mathrm{B}+\mathrm{NS}$ \\
\hline 200 & 205 & 207 & 31.5 & 0.69 & 1.76 & 1.28 & --- & --- & $\mathrm{B}+\mathrm{NS}$ \\
\hline 350 & 351 & 354 & 30.5 & 0.67 & 1.93 & 1.31 & --- & --- & $\mathrm{B}+\mathrm{NS}$ \\
\hline 500 & 496 & 503 & 30.1 & 0.66 & 2.03 & 1.37 & --- & --- & $\mathrm{B}+\mathrm{NS}$ \\
\hline 650 & 648 & 647 & 22.6 & 0.50 & 1.88 & 1.38 & --- & --- & B \\
\hline 800 & 800 & 797 & 11.3 & 0.25 & 1.58 & 1.48 & --- & --- & B \\
\hline \multirow[t]{3}{*}{950} & 950 & 951 & 3.8 & 0.08 & 1.33 & 1.25 & --- & --- & $\mathrm{B}$ \\
\hline & & & & Mean & 1.81 & 1.32 & & & \\
\hline & & & & $\mathrm{COV}$ & 0.135 & 0.062 & & & \\
\hline
\end{tabular}

Note: $\mathrm{B}$ = Bearing failure; NS = Net section tension failure.

(a) Series A-S-3-8 


\begin{tabular}{|c|c|c|c|c|c|c|c|c|c|}
\hline \multirow{2}{*}{\multicolumn{3}{|c|}{ Temperature $\left({ }^{\circ} \mathrm{C}\right)$}} & \multirow{3}{*}{$\begin{array}{c}P_{u, N} \\
\text { or } \\
P_{u, T} \\
(\mathrm{kN})\end{array}$} & \multirow{3}{*}{$P_{u, T} / P_{u, N}$} & \multirow{3}{*}{$\begin{array}{c}P_{u, N} / P_{A S C E} \\
\quad \text { or } \\
P_{u, T} / P_{A S C E}\end{array}$} & \multirow{3}{*}{$\begin{array}{l}P_{u, N} / P_{E C} \\
\quad \text { or } \\
P_{u, T} / P_{E C}\end{array}$} & \multicolumn{3}{|c|}{ Failure mode } \\
\hline & & & & & & & \multirow{2}{*}{$\begin{array}{c}\text { ASCE } \\
\text { and } \\
\text { AS/NZS }\end{array}$} & \multirow{2}{*}{$\mathrm{EC}$} & \multirow{2}{*}{ Test } \\
\hline Nominal & Coupon & Specimen & & & & & & & \\
\hline 22 & 22 & 22 & 41.7 & 1.00 & 1.94 & 1.33 & NS & NS & $\mathrm{B}+\mathrm{NS}$ \\
\hline 200 & 206 & 208 & 32.7 & 0.78 & 1.80 & 1.35 & --- & --- & $\mathrm{B}+\mathrm{NS}$ \\
\hline 350 & 356 & 357 & 31.4 & 0.75 & 1.81 & 1.29 & --- & --- & $\mathrm{B}+\mathrm{NS}$ \\
\hline \multirow[t]{2}{*}{500} & 498 & 503 & 33.4 & 0.80 & 2.05 & 1.41 & --- & --- & $\mathrm{B}+\mathrm{NS}$ \\
\hline & & 502 & 31.7 & 0.76 & 1.95 & 1.34 & --- & --- & $\mathrm{B}+\mathrm{NS}$ \\
\hline 650 & 645 & 649 & 27.0 & 0.65 & 1.88 & 1.38 & --- & --- & $\mathrm{B}+\mathrm{NS}$ \\
\hline 800 & 800 & 800 & 16.9 & 0.41 & 1.49 & 1.40 & --- & --- & B \\
\hline \multirow[t]{3}{*}{950} & 950 & 951 & 5.6 & 0.13 & 1.31 & 1.24 & --- & --- & $\mathrm{B}$ \\
\hline & & & & Mean & 1.78 & 1.34 & & & \\
\hline & & & & $\mathrm{COV}$ & 0.142 & 0.042 & & & \\
\hline
\end{tabular}

Note: $\mathrm{B}=$ Bearing failure; NS = Net section tension failure.

(b) Series T-S-3-8 


\begin{tabular}{|c|c|c|c|c|c|c|c|c|c|}
\hline \multirow{2}{*}{\multicolumn{3}{|c|}{ Temperature $\left({ }^{\circ} \mathrm{C}\right)$}} & \multirow{3}{*}{$\begin{array}{c}P_{u, N} \\
\text { or } \\
P_{u, T} \\
(\mathrm{kN})\end{array}$} & \multirow{3}{*}{$P_{u, T} / P_{u, N}$} & \multirow{3}{*}{$\begin{array}{c}P_{u, N} / P_{A S C E} \\
\quad \text { or } \\
P_{u, T} / P_{A S C E}\end{array}$} & \multirow{3}{*}{$\begin{array}{c}P_{u, N} / P_{E C} \\
\quad \text { or } \\
P_{u, T} / P_{E C}\end{array}$} & \multicolumn{3}{|c|}{ Failure mode } \\
\hline & & & & & & & \multirow{2}{*}{$\begin{array}{c}\text { ASCE } \\
\text { and } \\
\text { AS/NZS }\end{array}$} & \multirow{2}{*}{ EC } & \multirow{2}{*}{ Test } \\
\hline Nominal & Coupon & Specimen & & & & & & & \\
\hline \multirow[t]{2}{*}{22} & 22 & 22 & 52.2 & 1.00 & 1.54 & 1.30 & NS & NS & $\mathrm{B}+\mathrm{NS}$ \\
\hline & & 22 & 51.5 & 0.99 & 1.54 & 1.30 & NS & NS & $\mathrm{B}+\mathrm{NS}$ \\
\hline 200 & 206 & 208 & 42.5 & 0.81 & 1.61 & 1.28 & --- & --- & $\mathrm{B}+\mathrm{NS}$ \\
\hline \multirow[t]{2}{*}{350} & 356 & 356 & 43.2 & 0.83 & 1.82 & 1.33 & --- & --- & $\mathrm{B}+\mathrm{NS}$ \\
\hline & & 365 & 43.4 & 0.83 & 1.83 & 1.33 & --- & --- & $\mathrm{B}+\mathrm{NS}$ \\
\hline 500 & 501 & 501 & 39.7 & 0.76 & 1.90 & 1.36 & --- & --- & $\mathrm{B}+\mathrm{NS}$ \\
\hline 650 & 652 & 650 & 24.0 & 0.46 & 1.69 & 1.43 & --- & --- & B \\
\hline 800 & 795 & 799 & 9.3 & 0.18 & 1.67 & 1.44 & --- & --- & B \\
\hline \multirow[t]{3}{*}{950} & 948 & 949 & 1.9 & 0.04 & 2.26 & 1.62 & --- & --- & $\mathrm{B}$ \\
\hline & & & & Mean & 1.76 & 1.38 & & & \\
\hline & & & & $\mathrm{COV}$ & 0.129 & 0.078 & & & \\
\hline
\end{tabular}

Note: $\mathrm{B}$ = Bearing failure; NS = Net section tension failure.

\section{(c) Series L-S-3-8}

Table 6: Comparison of test results with predicted values for single shear three-bolted connections 


\begin{tabular}{|c|c|c|c|c|c|c|c|c|c|}
\hline \multirow{2}{*}{\multicolumn{3}{|c|}{ Temperature $\left({ }^{\circ} \mathrm{C}\right)$}} & \multirow{3}{*}{$\begin{array}{c}P_{u, N} \\
\text { or } \\
P_{u, T} \\
(\mathrm{kN})\end{array}$} & \multirow{3}{*}{$P_{u, T} / P_{u, N}$} & \multirow{3}{*}{$\begin{array}{c}P_{u, N} / P_{A S C E} \\
\quad \text { or } \\
P_{u, T} / P_{A S C E}\end{array}$} & \multirow{3}{*}{$\begin{array}{c}P_{u, N} / P_{E C} \\
\quad \text { or } \\
P_{u, T} / P_{E C}\end{array}$} & \multicolumn{3}{|c|}{ Failure mode } \\
\hline & & & & & & & \multirow{2}{*}{$\begin{array}{c}\text { ASCE } \\
\text { and } \\
\text { AS/NZS }\end{array}$} & \multirow{2}{*}{$\mathrm{EC}$} & \multirow[b]{2}{*}{ Test } \\
\hline Nominal & Coupon & Specimen & & & & & & & \\
\hline \multirow[t]{2}{*}{22} & 22 & 22 & 45.7 & 1.00 & 1.84 & 1.32 & NS & NS & $\mathrm{B}+\mathrm{BS}$ \\
\hline & & 22 & 45.4 & 0.99 & 1.86 & 1.34 & NS & NS & B \\
\hline 200 & 205 & 209 & 34.6 & 0.76 & 1.72 & 1.25 & --- & --- & B \\
\hline 350 & 351 & 356 & 33.4 & 0.73 & 1.88 & 1.35 & --- & --- & B \\
\hline 500 & 496 & 499 & 33.0 & 0.72 & 1.98 & 1.43 & --- & --- & B \\
\hline 650 & 648 & 648 & 24.1 & 0.53 & 1.78 & 1.31 & --- & --- & B \\
\hline 800 & 800 & 797 & 11.3 & 0.25 & 1.57 & 1.32 & --- & --- & B \\
\hline \multirow[t]{3}{*}{950} & 950 & 949 & 4.0 & 0.09 & 1.39 & 1.17 & --- & --- & $\mathrm{B}$ \\
\hline & & & & Mean & 1.75 & 1.31 & & & \\
\hline & & & & $\mathrm{COV}$ & 0.109 & 0.058 & & & \\
\hline
\end{tabular}

Note: $\mathrm{B}$ = Bearing failure; NS = Net section tension failure; BS = Bolt shear failure.

(a) Series A-S-4-6 


\begin{tabular}{|c|c|c|c|c|c|c|c|c|c|}
\hline \multirow{2}{*}{\multicolumn{3}{|c|}{ Temperature $\left({ }^{\circ} \mathrm{C}\right)$}} & \multirow{3}{*}{$\begin{array}{c}P_{u, N} \\
\text { or } \\
P_{u, T} \\
(\mathrm{kN})\end{array}$} & \multirow{3}{*}{$P_{u, T} / P_{u, N}$} & \multirow{3}{*}{$\begin{array}{l}P_{u, N} / P_{A S C E} \\
\quad \text { or } \\
P_{u, T} / P_{A S C E}\end{array}$} & \multirow{3}{*}{$\begin{array}{c}P_{u, N} / P_{E C} \\
\quad \text { or } \\
P_{u, T} / P_{E C}\end{array}$} & \multicolumn{3}{|c|}{ Failure mode } \\
\hline & & & & & & & \multirow{2}{*}{$\begin{array}{c}\text { ASCE } \\
\text { and } \\
\text { AS/NZS }\end{array}$} & \multirow{2}{*}{ EC } & \multirow{2}{*}{ Test } \\
\hline Nominal & Coupon & Specimen & & & & & & & \\
\hline \multirow[t]{2}{*}{22} & 22 & 22 & 44.2 & 1.00 & 1.80 & 1.30 & NS & NS & B \\
\hline & & 22 & 44.0 & 1.00 & 1.80 & 1.29 & NS & NS & B \\
\hline 200 & 206 & 206 & 35.9 & 0.81 & 1.76 & 1.31 & --- & --- & B \\
\hline 350 & 356 & 353 & 35.0 & 0.79 & 1.79 & 1.29 & --- & --- & B \\
\hline 500 & 498 & 501 & 35.1 & 0.79 & 1.92 & 1.38 & --- & --- & $\mathrm{B}$ \\
\hline 650 & 645 & 650 & 27.5 & 0.62 & 1.70 & 1.25 & --- & --- & $\mathrm{B}+\mathrm{BS}$ \\
\hline 800 & 800 & 804 & 13.9 & 0.31 & 1.22 & 1.03 & --- & --- & $\mathrm{B}+\mathrm{BS}$ \\
\hline \multirow[t]{3}{*}{950} & 950 & 950 & 4.9 & 0.11 & 1.14 & 0.96 & --- & --- & $\mathrm{B}+\mathrm{BS}$ \\
\hline & & & & Mean & 1.64 & 1.23 & & & \\
\hline & & & & $\mathrm{COV}$ & 0.178 & 0.121 & & & \\
\hline
\end{tabular}

Note: $\mathrm{B}=$ Bearing failure; $\mathrm{NS}$ = Net section tension failure; $\mathrm{BS}=$ Bolt shear failure.

(b) Series T-S-4-6 


\begin{tabular}{|c|c|c|c|c|c|c|c|c|c|}
\hline \multirow{2}{*}{\multicolumn{3}{|c|}{ Temperature $\left({ }^{\circ} \mathrm{C}\right)$}} & \multirow{3}{*}{$\begin{array}{c}P_{u, N} \\
\text { or } \\
P_{u, T} \\
(\mathrm{kN})\end{array}$} & \multirow{3}{*}{$P_{u, T} / P_{u, N}$} & \multirow{3}{*}{$\begin{array}{c}P_{u, N} / P_{A S C E} \\
\quad \text { or } \\
P_{u, T} / P_{A S C E}\end{array}$} & \multirow{3}{*}{$\begin{array}{l}P_{u, N} / P_{E C} \\
\quad \text { or } \\
P_{u, T} / P_{E C}\end{array}$} & \multicolumn{3}{|c|}{ Failure mode } \\
\hline & & & & & & & \multirow{2}{*}{$\begin{array}{c}\text { ASCE } \\
\text { and } \\
\text { AS/NZS }\end{array}$} & \multirow{2}{*}{$\mathrm{EC}$} & \multirow{2}{*}{ Test } \\
\hline Nominal & Coupon & Specimen & & & & & & & \\
\hline 22 & 22 & 22 & 60.1 & 1.00 & 1.78 & 1.49 & NS & NS & $\mathrm{B}+\mathrm{NS}$ \\
\hline 200 & 206 & 204 & 46.0 & 0.77 & 1.75 & 1.39 & --- & --- & $\mathrm{B}+\mathrm{NS}$ \\
\hline \multirow[t]{2}{*}{350} & 356 & 357 & 47.3 & 0.79 & 1.99 & 1.45 & --- & --- & $\mathrm{B}+\mathrm{NS}$ \\
\hline & & 358 & 47.4 & 0.79 & 2.00 & 1.46 & --- & --- & $\mathrm{B}+\mathrm{NS}$ \\
\hline 500 & 501 & 502 & 42.3 & 0.70 & 2.02 & 1.44 & --- & --- & $\mathrm{B}+\mathrm{NS}$ \\
\hline 650 & 652 & 647 & 24.7 & 0.41 & 1.74 & 1.48 & --- & --- & B \\
\hline 800 & 795 & 795 & 10.1 & 0.17 & 1.82 & 1.57 & --- & --- & B \\
\hline \multirow[t]{3}{*}{950} & 948 & 950 & 1.5 & 0.02 & 1.79 & 1.28 & --- & --- & $\mathrm{B}$ \\
\hline & & & & Mean & 1.86 & 1.45 & & & \\
\hline & & & & $\mathrm{COV}$ & 0.065 & 0.058 & & & \\
\hline
\end{tabular}

Note: $\mathrm{B}=$ Bearing failure; NS = Net section tension failure.

(c) Series L-S-4-8

Table 7: Comparison of test results with predicted values for single shear four-bolted connections 